\title{
Antik Yazarlarda Bir İskit Kraliçesi: Tomyris
}

\author{
Ancient Sources On A Scythian Queen: Tomyris
}

\section{Emre ERTEN*}

$\ddot{O}_{z}:$ İskit kraliçesi Tomyris hakkında antik yazarlarda hem kısıtlı hem de birbirinden farklı bilgiler vardır. Bunların tümü Tomyris ve Pers kralı Kyros arasındaki savaşla ilgilidir. Bu savaşta uygulanan iki savaş hilesi söz konusudur. Bunlardan biri Herodotos ve Iustinus'a göre Kyros'un uyguladığı şarap ve yemekli tuzaktır. Ancak bazı yazarlar bu tuzaktan hiç söz etmezken Polyainos ise bunu tam tersine Tomyris'e ait gösterir. Diğeri de Tomyris'e ait olan bozkır savaş taktiğidir. Bazı yazarların değindiği bu savaş hilesinden ise Herodotos ilginç biçimde söz etmemektedir. Çalışmada ağırlıklı olarak bu farklı yaklaşımların sebepleri üzerinde durulmakta ve Tomyris hakkındaki bilgiler karşılaş̧ırılmaktadır.

Anahtar sözcükler: İskitler, Tomyris, Kyros, Savaş Stratejisi

Abstract: In the surviving ancient sources there is only limited and inconsistent information concerning Tomyris, the Scythian queen and all of this information relates to the war between Tomyris and Kyros, the Persian king. There were two strategies employed in these wars. One, according to Herodotos and Iustinus, was the trap baited with wine and food and although some authors never mention this, Polyainos reported it as belonging to Tomyris. The other strategem of Tomyris was the steppe war. Herodotos, surprisingly, never mentioned this strategy, yet some ancient authors did. This study addresses the reasons of these different approaches and compares the information that has been related concerning Tomyris.

Keywords: Scythians, Tomyris, Kyros, ancient authors, strategem

Antikçağda âdeta efsaneleşmiş öyküsü ile pek çok antik yazarı etkilemiş olan Tomyris ünlü tarihçi Herodotos'a (I. 205) göre Massagetlerin kraliçesidir (ayrıca krş. Moorman-Uitterhoeve 1995, 684; Kytzler 1997, 161; Högemann 2002, 673). Orijinal şekli Tó $\mu$ pıı olan bu isme antik yazarlarda Tameris, Tamiris, Tamyris, Tomiris veya Tomaris olarak da rastlanmaktadır (Hermann 1930, 2128, 8; Ziegler 1937, 1702, 1-14, 1704 43). Gera bu ismin "demir" anlamina gelen Türkçe kökenli bir kelimeyle veya İran kökenli bir başka kelimeyle ilişkili olabileceğini belirtmektedir (Gera 1997, 187 dn. 2). Polyainos, Theon, Suda ve Strabon'da da Tomyris'ten Massaget olarak söz edilmekle beraber, pek çok antik yazarda Tomyris bir İskit kraliçesi olarak

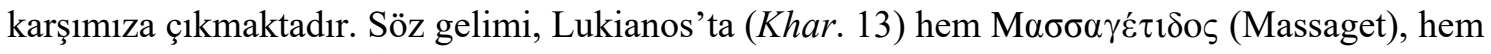

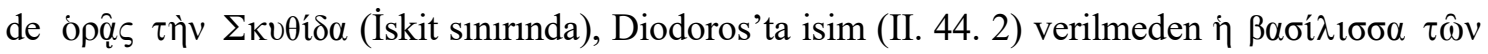
$\Sigma \kappa v \theta \omega ̂ v$ (İskitlerin kraliçesi); Frontinus, Iustinus, Orosius, Ammianus Marcellinus (Kyros’un

\footnotetext{
* Yrd. Doç. Dr., İstanbul Üniversitesi, Edebiyat Fakültesi, Eskiçağ Dilleri ve Kültürleri Bölümü, İstanbul. emre.erten@istanbul.edu.tr

Çalışmayı gözden geçirerek kıymetli zamanını ayırma nezaketini gösteren Doç. Dr. Ferit Baz’a teşekkürlerimi sunmayı bir borç bilirim.
} 
İskit seferi ile Dareios'unkini karıştıran bu yazar için bk. Ziegler 1937, 1703, 51-54), Ampelius ve Anthologia Latina gibi kaynaklarda da yine Scytharum regina (İskitlerin kraliçesi) olarak anılmaktadır (Ziegler 1937, 1702, 14-19; Gera 1997, 187 dn. 4 ve 188 dn. 5). Ünlü tarihçi Herodotos'a göre büyük ve güçlü bir ulus olan Massagetler, Hazar Denizi'nin doğusunda, kendileriyle Persler arasında doğal bir sınır teşkil eden Arakses Nehri'nin ötesindeki uçsuz bucaksız düzlüklerin büyük kısmını ellerinde tutarlardı (Hdt. I. 201-202, 204; ayrıca bk. Hermann 1930, 2125, 40 vd.; Schiltz 1994, 334; Gera 1997, 189-190; Sauter 2000, 138; Grakov 2006, 289). Günümüzde de Massagetlerin genel olarak Aral Gölü civarında yaşadıkları kabul edilmektedir (Gera 1997, 187; Högemann 2002, 673; Memiş 2005, 29). Diğer yandan Herodotos, Massagetlerin İskit soyundan olduklarını söyleyenlerin olduğunu belirterek onların giyim kuşam ve yaşam tarzı bakımından İskitlere benzediklerini anlatmakta ise de Massagetler ve İskitler arasında farklılık olduğunu da özellikle vurgulamaktadır. Söz gelimi erkeklerin tek kadınla evlenmeleri ama ortak faydalanmalarına dair bir âdeti Hellenlerin İskitlere yakıştırdığını ama bunun aslında Massagetlere ait olduğunu belirtir (Hdt. I. 201-204, 215-216; Hermann 1930, 2126, 25 vd.; Ziegler 1937, 1703, 26-30; Gera 1997, 188-189; Sauter 2000, 137-140). Diğer yandan Memiş $(2005,29$, 41-42), Massagetlerin Sakalardan nadiren ayırt edilebildiklerini fakat 1rksal tespitlerin kesin olmadığını belirtmektedir. Hermann (1920, 1787, 51-56), Kyros'un döneminde Saka adının Massagetler için de kullanıldığını söyler, Durmuş (2008, 8, 22, 42 ve 51) da Massagetleri İskit/Saka topluluklarının en büyük grubu olarak nitelemektedir (ayrıca krş. Burchard 2001, 1235). Diodoros (II. 43) ise Massagetleri bir İskit boyu olarak görürken, Strabon (XI. 8. 2) Hazar Denizi çevresinde hüküm süren İskitlerin Dahalar olarak adland1rıldıklarını belirtir. Dahaların MÖ IV. yüzyıldan itibaren Hazar Denizi ile daha doğudaki Okhos Irmağ bilinmektedir (Tezcan 2014, 55 vd.). Strabon (XI. 8. 2) buna ilave olarak daha doğudaki İskitlerin de Massagetler ve Sakalar olarak adlandırıldıklarını belirtir. Flavius Arrianos (anab. IV. 16. 4,7; 17. 1-7) Massagetleri Sogdiana'nın civarında oturan İskitler olarak görmekte ve Massagetlerle İskitlerin adını pek çok defa synonim olarak anmaktadır (ayrıca krş. Sauter 2000, 140 dn. 265). Hekataios ise Karadeniz İskitleri, Hazar Denizi'nin doğusundaki geniş düzlüklerde yaşayan Massagetler ve onların da doğusunda bulunan Sakai Amyrgioi adlı kavimlerden söz eder (Durmuş 2008, 8. Massagetler için özellikle bk. Hermann 1930, 2124 vd.; Sauter 2000, 139).

Massagetler tarih sahnesine ilk olarak büyük Pers kralı II. Kyros'un egemenliğinin son zamanlarında çıkarlar (MÖ 530/529). Bu dönemde bağımsızlıklarının Kyros’un düzenlediği bir seferle tehlikeye düştüğü anlaşılmaktadır. Herodotos gerek Massaget tarihinin bu kısmından gerekse onların kraliçesi Tomyris'ten detaylı şekilde bahseden kaynaklarımızın başında gelmektedir. Tarihçiye göre, giriştiği savaşlarda hep zaferler elde eden Pers kralı bu halkı da ele geçirmek için sabırsızlanmaktaydı. O sırada Massagetlerin başında, kocasının ölümünün ardından yönetimi ele almış olan Tomyris bulunmaktaydı. Duncker $(1853,576)$, bu halklarda esir düşen veya ölen kocalarının yerine eşlerinin yönetimi ellerine aldıklarını belirtir. Kyros elçiler göndererek onunla evlenmek istediğini bildirir, fakat bu isteğin altında yatan asıl sebebin ülkesinin yönetimini ele geçirmek olduğunu anlayan Tomyris bunu kabul etmez (Högemann 2002, 673). Bunun üzerine Kyros ordusunu Massagetlere karşı düzenleyeceği sefer için hazırlamaya başlar. Bu esnada Tomyris, Kyros'a bir elçi gönderir ve onu bu savaştan vazgeçirmeye çalışır. Şayet bu düşüncesinden vazgeçmeyecekse de Massagetlerin irmaktan üç günlük yol kadar çekileceğini ve o zaman ülkesine girmesini ya da istiyorsa Kyros'un aynı şeyi yapmasını söyler. Kyros, Pers ileri gelenleriyle durumu görüşür ve Lydialı Kroisos'un önerisi üzerine Massagetlerin ülkesine girmeye karar verir. Tomyris kendi yaptığı teklife uygun şekilde geri çekilir ve Kyros yönetimi 
oğlu Kambyses'e bırakıp Arakses Irmağı'nı geçer. Bir süre sonra da Kroisos'un önceden kendisine verdiği ögüdü tutarak Massagetleri kandırmak için bir miktar askerini bolca yemek ve şarapla bırakıp asıl savaşçı gücüyle geri çekilir. Massagetler bu hileye aldanarak saldırırlar ve bu az sayıdaki askeri yendikten sonra buldukları yiyecek-içeceklerle kendilerine bir şölen tertiplerler. İyice doyup yerlerinden bile kalkamaz hale gelince de Persler saldırıya geçer ve pek çoğunu öldürürler. Tomyris'in ifadesine göre Massaget ordusunun yaklaşık üçte biri yok edilmiştir (Hdt. I. 212). Bu arada Tomyris'in oğlu Spargapises'i de esir alırlar. Gera, bunun bir başka İskit adı olan ve Herodotos'ta (IV. 76) da anılan Spargapeithes ( $\left.\sum \pi \alpha \rho \gamma \alpha \pi \varepsilon i \theta n s\right)$ ile büyük benzerlik gösterdiğini belirtmekte ve İran kökenli bir isim olabileceğini düşünmektedir (Gera 1997, 198 dn. 42; ayrıca bk. Obst 1927, 1262). Bunun üzerine Tomyris, Kyros'a yeniden bir haberci gönderir. Haberci de onun bu zaferi Massagetlerin bolca içtiği şarap sayesinde yani hileli bir şekilde kazandığını söyleyip, Tomyris'in oğlunu geri vermesini ve ülkesinden çıkıp gitmesini, yoksa onu kana doyuracağını bildirir, fakat Kyros bu sözlere aldırmaz. Tam bu esnada Tomyris'in esir tutulan oğlu da bir firsatını bulup kendini öldürür. Bunun ardından Tomyris bütün kuvvetleriyle Kyros'un üzerine yürür. Uzun ve kanlı bir çarpışmanın ardından Massagetler galip gelir, Kyros da bu savaşta ölür. Tomyris savaş meydanında elinde kanla dolu bir tulumla Kyros'un cesedini arar ve bulunca da kesik kafasını bunun içine daldırır. Gera, Kyros'un başını gövdesinden bizzat Tomyris'in ayırdığını düşünmektedir (krş. Lukian. Khar. 13). Gera, Tomyris'in bunu cesetle alay etmek için yapmadığını, yalnızca daha önce verdiği sözü yerine getirmeyi amaçladığını eklemektedir. Gera bazı araştırmacıların Tomyris'in kesilen kafayı kanla dolu tuluma daldırması eylemini İskitlerde âdet olan ve Herodotos'un (IV. 64-66) da söz ettiği, öldürülen düşmanın kafasının kesilip şarap kupası yapılmasına yakın gördüklerini de belirtir (Gera 1997, 202-203 dn. 57). Ancak Tomyris'in sonradan Kyros'un başını bu amaçla kullanıp kullanmadığına dair bir bilgimiz bulunmamaktadır. Bizce, çok öfkeli olan Tomyris bizzat cesedin başında ifade ettiği gibi, bunu acımasız Kyros'u kanla doyuracağına dair önceden verdiği sözün gereği olarak yapmış görünmektedir. Nitekim Valerius Maximus, Iustinus ve Orosius da onun Kyros'u kana susamışlıkla suçlayan ifadelerine yer verirler ve Herodotos'un anlatımıyla benzerlik gösterirler. Herodotos burada anlatımını bitirirken Kyros'un ölümüyle ilgili başka pek çok öykü olduğunu fakat kendisine en doğru görüneni naklettiğini vurgular. Herodotos'un (I. 204-214) bu olayla ilgili anlatımıla Iustinus, Lukianos, Suda ve Valerius Maximus'unkiler uyuşmaktadır (Ziegler 1937, 1702, 58-59; Duchesne-Guillemin 1979b, 885).

Tomyris hakkında bilgi veren belli başlı diğer yazarlara baktığımızda bunlardan ilk göze çarpan MÖ I. yüzyıl yazarlarından Diodoros'tur (II. 44. 1-2). Diodoros'un Bibliotheke Historike adlı eserindeki anlatıma (II. 43. 5) göre, o zamanın en güçlü krallarından biri olan Kyros çok büyük bir orduyla "İskit" ülkesine sefere çıkmış fakat "bir İskit kraliçesi" Perslerin ordugâhını yıkmış, kralları Kyros'u yakalamış ve çarmı ha germiştir (ayrıca krş. Weißbach 1924, 1157; Ziegler 1937, 1703; Gera 1997, 202). İlginç şekilde Tomyris'in adını vermeyen Diodoros ayrıca Kyros'u yenilgiye uğratanların Massagetler olduğunu da belirtmemekte ve bunları 'İskitler' olarak tanımlamaktadır. Ziegler'e (1937, 1703) göre, Diodoros bu öyküyü Amazonlara benzeyen İskit kadınlarının erkeklere denk olan erdemlerine kanıt sunmak için nakletmiştir.

Bir başka kaynak ise Biblioteca Medicea Laurenziana'da muhafaza edilen MS XII.-XIII. yüzyıldan kalma Codex Laurentianus gr. 56-1'in içinde yer alan ve olasılıkla MÖ II. veya I.

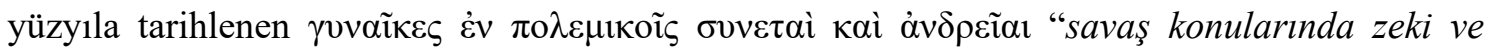
cesur kadınlar" başlı̆̆ıyla yer alan küçük bir çalışmadır (Gera 1997, 6-11, 30; Brodersen 2010, 151 vd.; Erten 2016, 100-101). Modern literatürde Anonymus Tractatus de Mulieribus Claris in Bello veya Anonymus de Mulieribus olarak da anılan bu küçük çalışma, adından da anlaşılacağ üzere anonim bir eser olup, özellikle savaş alanında önemli yararlılıklar göstermiş olan on dört 
Hellen ve barbar kadınla ilgili kısa notlar içermektedir. Söz konusu kadınlarla ilgili bu çalışmanın dayandığı kaynaklar ise genellikle MÖ V.-IV. yüzyıllarda faaliyet göstermiş yazarlar olup, neredeyse hepsinden isimleriyle söz edilmektedir (Gera 1997, 3; ayrıca krş. 28-29). Nitekim Tomyris hakkındaki bilgilerin de Herodotos'tan alındığı açıkça belirtilmektedir. Buna göre Kyros, bir oğlu olan Massaget kraliçesi Tomyris'e anlaşma olană̆ bulunmayan bir savaş ilan ettiği zaman, Tomyris Kyros'a, öncelikle kendi ülkesinde barış içinde kalmasını ya da gerçekten savaşmak istiyorsa üç günlük bir mesafe kadar geri çekilerek ordusuyla beraber Tomyris'i orada karşılamasını ya da tam tersini yapıp İskitlerin ülkesine aynı şekilde girmesini söyler. Kyros da ona karşı ilerleyip, savaşta galip gelir. Oğlu canlı olarak Perslerin eline düşünce Tomyris tekrar haber gönderir ve bu zaferle yetinip onu kendisine geri vermesini ve ülkesine dönmesini söyler. Fakat Kyros, çocuğun intihar ettiğini bildiği için bu teklifi reddedince, Tomyris bütün ordusuyla saldırıp sadece kazanmakla kalmaz aynı zamanda ölmüş olan Kyros'u bulup oğluna karşılık onun cesedine zarar verir. Görüldügü gibi bu çalışma ile Herodotos'un anlatımı arasında önemli benzerlikler olduğu açıktır. Özellikle de savaştan önce Tomyris'in Kyros'u vazgeçirmeye çalışması ve üç günlük mesafe ile ilgili teklifi, bu çalışmada Herodotos'tan yararlanıldığını göstermektedir. Ancak bu noktada bazı önemli farklılıkların bulunduğunu da göz ardı etmemek gerekir. Bunların içinde en çok göze çarpan kuşkusuz Kyros'un cesedine yapılan muamele ile ilgilidir. Nitekim Herodotos'un yanı sira Tomyris hakkında bilgi veren Valerius Maximus, Lukianos, Iustinus, Sidonius, Orosius gibi kaynaklarda Kyros'un başının kesilerek kan dolu bir tuluma sokulduğundan bahsedilmesine rağmen burada söz konusu çarpıcı detaya yer verilmediği görülmektedir (Gera 1997, 203 dn. 58, 204). Ancak bu çalışma ile Herodotos arasındaki farklılıklar bununla da sınırlı değildir. Söz gelimi olay öncesinde Kyros'un Tomyris'e yaptığı evlilik teklifinin reddedilmesi, savaş hazırlıkları, Kroisos'un önemi ve tavsiyeleri, Kyros'un kurduğu şarapl1-yemekli tuzak, Tomyris'in bununla ilgili öfke dolu sözleri ve intikam yemini, Persler ve Massagetler arasında gerçekleşen ikinci ve çok şiddetli çarpışma ile bunun sonunda Tomyris'in yaptığı trajik konuşma da Herodotos'ta olan fakat bu çalışmada yer verilmeyen önemli detaylardır. Gera, Herodotos'ta beliren Tomyris'in karanlık, coşkulu ve dramatik yönünün bu çalışmada tümüyle göz ardı edildiğini belirterek, dolayısıyla sadece bu bilgilerin değil aynı zamanda Herodotos'taki renkli ve etkileyici anlatımın da tümüyle kaybolduğunu vurgulamaktadır. Diğer bir önemli farklılık da çalışmada Spargapises'in isminden söz edilmeyerek sadece Tomyris'in 'oğlu' olarak anılmasidır. Gera (1997, 198, 201 ve 204), burada Tomyris'in sade bir anlatımla yalnızca kederli ve kindar bir anne olarak gösterildiğini, fakat onun asil, güçlü ve bilge bir kraliçe olarak bundan daha derin bir niteliğe sahip olduğunu belirtmektedir. Bunun yanı sıra, söz konusu çalışmada Iustinus, Frontinus, Diodoros ve Polyainos gibi kaynaklardaki başka bilgiler de yer almamaktadır.

MS I. yüzyılda imparator Tiberius zamanında yaşamış olan Valerius Maximus da Facta et Dicta Memorabilia (Anılmaya Değer Isşler ve Sözler) adlı eserinde (IX. 10, ext. 1), Tomyris'e çok kısaca değinir. İntikam konusunda meşhur olmuş iki kadından birisi olarak Tomyris'e değinen yazar, Kyros'u kana doymazlıkla suçlayarak onun başını kestirdiğini ve insan kanıyla dolu bir tuluma soktuğunu söyleyerek bunu oğlunu öldürdüğü için yaptığını vurgular. Yazar Tomyris'in oğlunun adını vermez, ayrıca Herodotos'un aksine intihar ettiğinden değil, Kyros tarafından öldürtüldüğünden söz eder.

Yine MS I. yüzyıl yazarlarından Sextus Iulius Frontinus ise, Strategemata adlı eserinde, sadece İskitlerin kraliçesi "Tamyris" ile Pers kralı Kyros savaştığ sırada "Tamyris 'in" bir kaçış hilesiyle onu kendi askerlerinin iyi bildiği dar geçitlere çektiğini ve orada ansızın geri dönüp arazinin de yardımıyla büyük bir zafer kazandığını anlatmakla Herodotos'tan tamamen farklı bir 
bilgi sunmaktadır (Frontin. II. 5. 5; ayrica bk. Erim 1987, 215).

Bir diğer kaynak ise MS II. yüzyıl yazarlarından olan ve farklı etnik kökenlerden çok sayıda komutana ait yüzlerce savaş taktiğini bir araya getiren Makedonyalı Polyainos'tur. Roma'da hatip ve avukat olarak faaliyet gösteren yazar, MS 161-162 yıllarında dönemin Roma imparatorları Marcus Aurelius ve Lucius Verus'a Parth savaşları sırasında faydalı olması için kaleme aldığı Strategemata adlı eserinde bu olaya da çok kısaca değinmektedir. Ancak yazar, aşağıda daha geniş biçimde ele alacağımız gibi şarap ve yemekli tuzağı kuran kişi olarak Herodotos'un tam aksine Tomyris'i göstermekte ve Perslerin büyük yenilgisini de ikinci bir savaştan söz etmeyip doğrudan bu olaya bağlamaktadır (Polyain. VIII. 28. Polyainos ve eseri için bk. Melber 1885; Lammert 1952, 1432-1436; Kroh 1972, 507; Meister 2001, 40-41; Geus 2010, 55-68).

MS II.-III. yüzyıl (?) yazarlarından olan Marcus Iunianus Iustinus da Herodotos ve Frontinus'un karışımından oluşan bir anlatım sunmaktadır. Iustinus hakkında eldeki bilgiler oldukça sınırlı olup, Pompeius Trogus'un eserinin bir özetini (epitomos) yazdığı bilinmektedir (Iust. I. 8; ayrıca bk. Erim 1987, 178; Grakov 2006, 22. Iustinus'un, Tomyris hakkındaki anlatımıyla benzerlik gösteren yazarlar için bk. Ziegler 1937, 1703, 44-49 ve DuchesneGuillemin 1979b, 885). Iustinus'un verdiği bilgiye göre Kyros, Asia'ya boyun eğdirdikten bir süre sonra İskitlerle savaşmıştır. $\mathrm{O}$ zamanlar Tomyris İskitlerin kraliçesidir. Kadın olmasına rağmen düşman karşısında korkuya kapılmamış, aslında engelleyebileceği halde Perslerin arada sınır teşkil eden Arakses Nehri'ni geçmesine izin vermiş̧; bunu da savaş sırasında kendisinin iyi bildiği topraklarda bazı firsatlar yaratmak ve düşmanın geri çekilme yolunu nehir yardımıyla kesmek istediği için yapmıştır. Böylece Kyros Nehri geçer ve İskit ülkesinde bir süre ilerleyip sonunda ordugâhını kurar. Ardından Kyros korkuya kapılmış gibi davranarak geri çekilir ve ordugâhı bolca şarapla ve bir şölende olabilecek her şeyle beraber terk eder. Tomyris bunu duyunca ordusunun üçte birlik kısmını oğluyla birlikte gönderir. Kyros'un ordugâhına vardıkları zaman bu tecrübesiz genç komutan savaşın asıl hedefini unutarak âdeta bir şölen verir ve barbarlar düşmanı hesaba katmadan "alışık olmadıkları" şarapla sarhoş olurlar. Kyros onların bu durumunu haber alınca geceleyin geri döner ve kraliçenin oğluyla beraber hepsini yok eder. Iustinus'a göre Tomyris, ordusunun bu kadar büyük bir kısmını ve biricik oğlunu kaybetmesinden dolayı gözyaşlarına boğulmak yerine acısına teselli bulabilmek için intikam peşine düşer ve bu zaferden dolayı sevinç içinde olan düşmanı bir tuzağa çekmek üzere harekete geçer. $\mathrm{Bu}$ yenilgi yüzünden kendine güvenini yitirmiş ve korkmuş gibi davranan Tomyris geri çekilir ve Kyros'u dar geçitlere doğru çeker. Buradaki dağlarda bir pusu kurarak iki yüz bin Pers askerini Kyros ile beraber yok eder. Iustinus'a göre bu savaşın bir diğer şaşılacak yönü bu kadar büyük Pers ordusundan geriye bir tek habercinin bile kalmamış olmasıdır (Aynı doğrultuda bilgi veren diğer kaynaklar için bk. Gera 1997, 202 dn. 53). Sonra Tomyris Kyros'un kesik başını insan kanıyla dolu bir tulumun içine sokar ve acımasız Kyros'u böylece kana doyurduğunu söyler. Son olarak da Kyros'un aralıksız olarak 30 yıl boyunca çok başarılı bir hükümdar olduğunu ilave eder. Gera, Tomyris'in kederinden ve erkeksi cesaretinden söz eden Iustinus'un oldukça renkli ve patetik bir üslûp kullandıklarını belirtmektedir (Iust. I. 8; ayrıca bk. Gera 1997, 204).

Tomyris ile ilgili bu anlatımın ilk kısmında Iustinus ve Herodotos büyük ölçüde benzeşmektedir. O da tıpkı Herodotos gibi Kyros'un İskit ülkesinde ilerleyişini, İskitlere karşı şarap ve yemekle uyguladığı taktiği ve barbarların ordusunun üçte birinin yok edildiğini anlatır. Bununla beraber bazı farkl11ıklar da yok değildir. Nitekim bunlardan ilk göze çarpan, Iustinus'un sürekli olarak 'İskitlerden' söz etmesi ve iki kavim arasındaki ayrımı dile getiren Herodotos'un aksine Massagetlere değinmemesidir. Ayrıca Herodotos, Tomyris'in ilk başta Kyros'u savaştan vazgeçirmeye çalışmasına, sonrasında karşılıklı üç günlük yol mesafesinde savaş yapılmasına 
dair teklifine yer verirken, Iustinus bundan bahsetmemektedir. Fakat bu kısımdaki en önemli farklılık şüphesiz Herodotos'un, Tomyris'in oğlunun esir edilip sonradan kendini öldürdüğünü anlatmasına karşılık Iustinus'ta onun Kyros'un düzenlediği gece baskını sırasında öldürüldügünden söz edilmesidir. Bundan sonra Perslerin yenilgisiyle son bulan ikinci çarpışmayla ilgili olarak ise Iustinus, Herodotos'u birakarak Frontinus'taki anlatımın bir benzerini aktarmaktadır. Bu kısımda Herodotos ile arasındaki en önemli farklılık Iustinus'un, Perslerin Tomyris tarafından dağlarda kurulan tuzağa düştüğünü belirtmesine karşl1ık, Herodotos'un böyle bir tuzaktan hiç söz etmemesidir. Ayrıca yine bu ikinci savaşla ilgili olarak Iustinus ile hem Herodotos hem de Frontinus arasında bir başka farklılık daha göze çarpmaktadır; Iustinus Pers ordusunun bu faciayı haber verecek tek kişi bile kalmayacak şekilde yok edildiğini savunurken Herodotos onların 'büyük kısmının' katledildiğini söylemekte, Frontinus ise herhangi bir say vermemektedir. Iustinus ile Frontinus arasındaki bir diğer önemli fark ise, Iustinus'un bu savaşta Kyros'un öldüğünü söylemesine ve bununla ilgili detaylar vermesine karşıllk, Frontinus'ta kraliçenin Kyros karşısında tam bir zafer kazandığının belirtilmesi, ancak Pers kralının bu savaşta öldügünün açıkça dile getirilmemesidir (Hdt. I. 214 krş. Frontin. II. 5. 5). Bunun ardından Iustinus son olarak tekrar Herodotos'un anlatımına dönmekte ve benzer şekilde Tomyris'in içi kan dolu bir tuluma Kyros'un kesik başını koymasıyla ilgili detaylara yer vermektedir (Iustinus ile başka yazarlar arasındaki benzerlikler ve bunların Tomyris hakkındaki görüşleri için bk. Ziegler 1937, 1703, 44-57).

Tomyris ile Kyros arasında yaşanan bu olayın yankılarının MS VI. yüzyıla gelindiğinde bile halen devam ettiği anlaşılmaktadır. Nitekim Got yazar Iordanes de eserinde bu konuyu kısaca ele almış fakat farklı bir şekilde anlatmıştır. Yazar Kyros'un seferiyle daha sonra gerçekleşen Dareios'unkini karıştırmış ve Tomyris'i de büyük olasılıkla Massagetlerden esinlenerek bir Get kraliçesi gibi göstermiştir (Ziegler 1937, 1704, 37; Fuhrmann 1979, 1439. Orta Çağ ve daha sonrasında Tomyris hakkındaki anlatımlar ve tasvirler için bk. Moorman-Uitterhoeve 1995, $685)$.

Görüldüğü üzere, Tomyris hakkındaki mevcut bilgilerimizin tümünü Kyros ile aralarında gerçekleşen savaşta yaşanan hâdiseler oluşturmaktadır. Ancak bu savaşa dair antik yazarlarda çeşitli anlatımlar bulunmakta ve bunların bir kısmı birbiriyle örtüşürken bir kısmı ise önemli farklılıklar göstermektedir. Weißbach $(1924,1156)$, Herodotos'un yazdıklarını süslü bir anlatım olarak nitelemekle beraber, Kyros'un ölümüyle ilgili kaynaklar arasında en geniş yeri ona ayırmakta, ayrıca tarihçinin bu anlatımıyla antik dönemde derin bir yankı uyandırdığını ve pek çok yazarın ondan etkilendiğini belirtmektedir. Ziegler de, her ne kadar Herodotos'un anlatımının hikâye tarzında olduğunu belirterek, hem Kyros'un Massaget seferi hem de eski Pers, Med ve Suriye tarihi hakkındaki bilgilerin, antik tarih yazarlarının anlatılanlara kolay inanmalarından ve efsanelere düşü̈nlüklerinden dolayı fazla güvenilir olmadığı şeklindeki Strabon'un (XI. 6. 2) uyarısını hatırlatsa da, diğerlerinin yanında söz konusu olaya en yakın zaman dilimine ait olması nedeniyle Herodotos'un tarihsel gerçekliğe en yakın bilgileri aktardığını söylemektedir (krş. Duchesne-Guillemin 1979b, 885). Ziegler ayrıca Tomyris'in Kyros'a elçi göndererek savaşın yeri ve zamanı hakkında teklif sunmasına dair anlatımın da doğru bilgiye yönelik bir ipucu olarak görülebileceğini belirterek, bununla Vercellae Savaş1 arasındaki benzerliğe vurgu yapmaktadır. Bilindiği üzere, kuzey İtalya'da MÖ 101 yılında gerçekleşen Vercellae Savaşı'nda Kimberlerin önderi Boiorix, Marius'a savaşın günü ve yerinin kararlaştırılması konusunda teklifte bulunmuştur (Klebs 1897, 636). Ziegler (1937, 1704, 17-36) ayrıca konuya ilişkin Herodotos dışındaki antik yazarları ikinci dereceden ve 'Pers yanlısı' kaynaklar olarak nitelemekte ve bunların Kyros'u bir meydan savaşında yenilmiş göstermek yerine barbarca bir tuzağa düşmüş gösterdiklerini ileri sürmektedir. Hermann (1930, 2128, 3 
vd.) da, anekdotlarla süslenmiş olsa bile Massaget tarihinin bu kısmıyla ilgili bilgileri Herodotos'a borçlu olduğumuzu belirterek tümüyle tarihçinin eserinden yararlanmaktadır. Aynı şekilde Rolle de Herodotos'taki bu anekdotu kabul etmekte; Schiltz ise doğrudan Herodotos'un anlatımına yer vermekle kalmayıp, oğlunun intikamını alan Tomyris'i de "acımasız" olarak nitelemekte; Moorman-Uitterhoeve (1995, 684-685) ve Kytzler (1997, 161-162) de Tomyris ile ilgili hikâyeyi tamamen Herodotos'a dayandırmakta ve diğer yazarlardaki bilgilere yer vermemektedirler (ayrica bk. Rolle 1980, 94; Schiltz 1994, 334). Durmuş'a (1993, 5-6 ve 10) göre de Herodotos İskitler hakkında elimizdeki en önemli kaynaktır ve verdiği bilgilerin çoğu arkeolojik kazılarla ispatlanmış olup, bazı yanlışları olsa da diğer antik yazarlara göre en eski tarihli bilgileri sunması bakımından da eseri İskit tarihi açısından son derece değerlidir ve "eşi bulunmaz" bir kaynaktır. Högemann $(2002,673)$ da, Herodotos'u elde bulunan kaynakların en eskisi ve güvenilir olanı şeklinde tanımlayarak yalnızca onun verdiği bilgilerin bir özetini nakletmektedir.

Buna karşılık bazı modern araştırmacılar ise Herodotos'ta anlatılan bu olaya şüpheyle yaklaşmaktadırlar. Nitekim Duchesne-Guillemin (1979a, 418), Kyros'un krallığın kuzeydoğusu veya doğu sınırlarında barbar bir halkla savaşırken öldüğünü belirtmekte ve cesedinin de Kambyses tarafından Pers ülkesine gönderildiğini ileri sürmektedir. Benzer şekilde Grakov (2006, 18 ve 290), Herodotos'un verdiği bilgilerin faydalı olduğunu söylemekle birlikte, Tomyris ile ilgili anlatımı 'efsanevî' olarak niteleyerek Kyros'un başının kan dolu bir tuluma konulması hadisesine şüpheyle yaklaşmakta ve cesedinin de kesinlikle düşmanların eline geçmediğini, aksine Pasargadai'a gönderildiğini belirtmektedir. Osten $(1965,66)$ de, Kyros'un krallığın kuzeydoğusunda gerçekleşen savaşlarda öldüğünü belirtir, ancak bununla bağlantılı olarak Tomyris'ten ve İskitlerden hiç söz etmediği gibi o da Kyros'un cesedinin Pasargadai'da gömüldügünü söyler. Gera da eldeki kaynakların Kyros'un ölümüne dair Herodotos'ta bulunan bilgileri doğrulamak konusunda yeterli olmadığını, Herodotos'un da bizzat söylediği gibi, pek çok kaynak arasından kendisine en makul görüneni seçtiğini vurgulayarak, o da Grakov gibi, Perslerin yenilgiden sonra Kyros'un cesedini alıp Pasargadai'a götürdüklerini, ayrıca Tomyris'in varlığını bile kesin olarak tespit etmenin mümkün olmadığını vurgulamaktadır (Gera 1997, 203 dn. 63 krş. Wiesehöfer 1999, 1018). Duncker ise, bir defasında Kyros'un Sakalara karşı düzenlediği bir seferde, onların kraliçesine yenik düştüğüne dair anlatımların olduğunu ve bu olayın Asya'nın hâkimi olan bu büyük kralın bir kadına yenildiği ve ölümü de onun elinden tattığ şeklindeki bazı şiirsel yansımalara yol açmış olabileceğini belirtmektedir (Sauter, Ktesias'ın bildirdiği bu savaşın Saka kraliçesi Spamithre’ye karşı yapıldığını belirtir, bk. Sauter 2000, 140 dn. 265 krş. FGrHist 688 F 9. 3. bazı araştırmacılar ise onun adını Sparethra olarak verirken, Llewellyn-Jones \& Robson ise bunu Sparethe olarak nakleder, bk. Duncker 1853, 572; Weißbach 1924, 1137, 41; Gera 1997, 199-200; Llewellyn-Jones \& Robson 2010, 171. Hermann da, Herodotos'un verdiği bilgilerin nispeten güvenilir oluşuna dayanarak, Kyros'un Sakalara karş1 yaptığı seferlerin MÖ 546-540 yıllarında, yani Lydia krallığının düşmesiyle Babil savaşının başlangıcı arasında meydana geldiğini öne sürmektedir, bk. Hermann 1920, 1799, 30-50; ayrıca krş. Hdt. I. 153 ve 177. Ancak, yukarıda değinilen savaştan sonra, kraliçenin kocası Amorges'in Kroisos'a karşı Kyros'a yardım ettiği bilindiğinden söz konusu olayın MÖ 546'dan daha önce gerçekleşmiş olması gerekir, bk. Gera 1997, 200; Sauter 2000, 136; Durmuş 2008, 36-37; Llewellyn-Jones \& Robson 2010, 171). Bunun dışında Duncker $(1853,576)$, yine Sakalara karş1 yapılan bir savaşta da, Herodotos'un Massagetlere karşı kullanıldığını söylediği yiyecekiçecekle dolu bir ordugâhın düşmana bırakılması taktiğinin uygulandığını belirterek, Sakalarla yapılan savaşlardaki bu tür ilgi çekici olayların sonradan Massagetlere uyarlanmış olabileceğini, zira Kyros'un Pers krallığının kuzeydoğu sınırlarındaki bir savaşta öldüğünün bilindiğini dile 
getirmektedir (Hermann 1920, 1776, 16; ayrıca krş. Strab. XI. 8. 5).

Tomyris ve Kyros arasındaki savaşla ilgili bilgi veren antik kaynaklara bakıldığında bunların arasında iki temel farklılık olduğu görülmektedir. Bunlardan ilki, Herodotos'ta anlatılan Kyros'un uyguladığı bol şarap ve yemekli savaş hilesinden bazı yazarlarca ya hiç söz edilmemesi ya da tam tersine Tomyris tarafından uygulanmış gibi gösterilmesidir. İkincisi ise bazı yazarlarca Tomyris'in uyguladığı söylenen dağ geçitlerine doğru geri çekilerek Persleri tuzağa düşürme taktiğinin Herodotos'ta yer almamasıdır. Bunların ilki ve şüphesiz en ilgi çekici olanı düşman kuvvetlerine "bol şarap ve yemek birakmak" suretiyle kurulan tuzak olup, yukarıda da değindiğimiz gibi Herodotos ve Iustinus'a göre birinci çarpışmada Persler tarafindan Massagetlere/İskitlere karşı uygulanmıştır. Hatta Herodotos'un (I. 207) anlatısına göre, Pers kralına bu tuzağı kurmasını öğütleyen kişi, esir durumdaki meşhur Lydia kralı Kroisos'tur. Gerçekten de Kroisos Massagetlerin topraklarında savaşmanın gerekliliğini açıkladıktan sonra Kyros'a şu sözleri söyler:

"Massagetler Perslerdeki inceliği bilmezler. Bu adamları denemek için sürülerimizden birçok hayvan öldürelim, yemekler pişirtelim, konak yerimizde büyük bir şölen verelim; masrafa bakmadan şarap, yemek ne varsa hepsini ortaya dökelim. Sonra konak yerinde ordumuzun en az işe yarayanların bırakıp, geri kalanin toplayarak ırmă̆a doğru geri çekilelim. Ya büsbütün yanıllyorum ya da onlar bu kadar güzel şeyi bir arada görünce üzerine atılacaklar ve kendimizi göstermek için meydanı bize bırakacaklar".

Gerçekten de kısa bir süre sonra Persler bu hilenin yardımıyla Massagetleri büyük bir yenilgiye uğratırlar. Ancak yukarıda da değindiğimiz üzere Polyainos ise bu tuzağı kuran kişi olarak şaşırtıcı şekilde Kyros'u değil tam tersine Tomyris'i göstermekte ve böylece Herodotos ile Iustinus'tan tümüyle ayrılmaktadır. Polyainos'un (VIII. 28) bu olayla ilgili sözleri şöyledir:

"Kyros kendisine doğru sefere çıktı̆̆ında Tomyris düşmanlardan korkmuş gibi davrandl. Massaget ordusu kaçtı, Pers ordusu da peşinden gitti ve onların ordugâhında bol miktarda şarap, yemek ve kurbanlık hayvanla karşılaş̧t. Persler, sanki bir zafer kazanmış gibi, bütün gece boyunca bunları hiç tereddüt etmeden bolca yiyip içtiler. Ancak tıka basa doyduktan sonra uykuya daldıklarında Tomyris ansızın gelip yerlerinden bile kipırdayamayacak haldeki Persleri Kyros da dâhil olmak üzere katletti”.

Görüldüğü gibi, Polyainos'a ait bu pasajla elimizdeki en güvenilir kaynak durumundaki Herodotos'un ve onunla benzer bilgiler veren Iustinus'un anlatımları tam bir tezat teşkil etmektedir. Bu nedenle söz konusu tuzağın gerçekte kimin tarafindan kurulmuş olabileceğine dair bir şüphe uyanmakta ve bu da olayın bazı açılardan yeniden gözden geçirilmesini gerekli kılmaktadır. Öncelikle, pek çok bilim insanının da belirttiği üzere, yaşananlara "zamansal" yakınlığından dolayı Herodotos eldeki en güvenilir kaynak ise, bu tuzağın Perslerce kurulduğuna dair açık ifadesini görmezden gelmek de doğru bir yaklaşım olmayacaktır. Ayrıca ünlü tarihçinin buna ilave olarak, mertçe gerçekleşen bir meydan savaşı yerine böyle bir hileyle mağlup edilmiş olmaktan dolayı öfkeli olduğu anlaşılan Tomyris'in sözlerine tüm canlılığıyla yer vermiş olmasını da göz ardı etmemek gerekir:

“...Kana doymayan kanlı katil Kyros, bu başariyla övünme; bu zaferi, içtiğiniz vakit sizin de aklınızı başınızdan alan, damarlarınıza indiği ölçüde size kötü sözler söyleten üzüm kazandl. Bu zehirdir/iksirdir seni hilebazlıkla oğlumun efendisi yapan; bu, güçlerin boy ölçüştüğü bir 
savaş değildi...” (Hdt. I. 212).

Ancak, Herodotos'un bu açık ve kesin ifadelerine bakarak tam aksi yönde bilgi veren Polyainos hakkında kolay ve hızlı bir hüküm vermektense söz konusu tuzağı gerçekten kimin kurmuş olabileceği konusunu ele almak bizce daha doğru görünmektedir. Bu noktada ilk yapacağımız şey, şarabın "başrolü" oynadığı böyle bir hileye aldanma olasılığına Persler ve İskitlerdeki "şarap kültürü" açısından kısaca göz atmak olacaktır. Bu bağlamda Perslerin içki tradisyonlarına dair Herodotos’ta (I. 133) ilginç bilgiler yer almakta olup, ünlü tarihçinin aşağıdaki sözleri dikkat çekicidir:

"Persler şarabı çok severler, fakat başkalarının yanında kusmak, abdest bozmak yasaktır... En ciddi konuları içerek konuşmak görenekleri arasındadır. Ĕger bir karar kadeh sesleri içinde verilmişse ertesi gün... karar kimin evinde verilmişse o işi yeniden oya koyar eğer aylk kafayla da olur derlerse o karar yürütülür, yoksa vazgeçilir; bunun tersine olarak ayık kafa ile düşünülmüşs olan bir şey de içki havası içinde yeniden ele alını"."

Herodotos'un (I. 131-140) verdiği "pozitif" etki uyandıran bu bilgiler büyük olasıllıla onun Hellenlere Persleri "doğru bir şekilde" tanıtma çabasının bir ürünü olup, tarihçi eserinin bu kısmında onlara ait başka pek çok gelenek ve göreneği de aynı amaçla bir araya getirmeye çalışmaktadır. Onun yukarıdaki sözlerine bakıldığında Perslerin gelişkin bir şarap kültürüne sahip oldukları varsayılabilir. Dolayısıyla bu anlatım ilk bakışta Pers askerlerinin düşman ordugâhında buldukları şarabı böyle bir tuzağa düşecek kadar "ölçüsüzce" tükettiklerine dair Polyainos'un verdiği bilgiyi çürütmek için kullanılabilecek bir ipucu gibi görünmektedir. Ancak Perslerin şarap karşısındaki durumlarına dair yine Herodotos'un eserinin bir başka yerindeki bazı bilgiler (I. 71) de bunun tam tersi yönde bir görünüm yaratmaktadır. Nitekim Lydia kralı Kroisos Perslere saldırmadan önce, bilge birisi olan Sandanis adlı bir Lydialı ona şu öğütte bulunmaktadır:

"Kral, savaşa tutuşmaya hazırlandiğın bu insanların ne halde olduklarını bir düşün... istedikleri kadar değil buldukları kadar yerler, zira toprakları taştır. Şarap içmesini de bilmezler, içkileri sudur... Ellerinde bir şeyleri olmadı̆̆ına göre bunlarl alt etsen eline ne geçecek? Bir kez bizdeki şeylerin tadına vardılar mi yapışacaklar ve bir daha da bırakmayacaklar. Bana kalırsa tanrılara şükrediyorum Perslerin kafasına Lydia üzerine yürümek düşüncesini sokmuyor diye... Gerçekten de Perslerin Lydialılarl yenmeden önce bir tek lüksleri ve iyi bir şeyleri yoktu".

Görüldüğü üzere, Sandanis'e ait bu sözler Perslerin şarap karşısındaki durumlarına dair tarihçinin diğer olumlu sözleriyle çelişmektedir. Özellikle de "şarap içmeyi bilmezler, içkileri sudur" şeklindeki ifade Perslerin de şarap karşısında zor durumlara düşebileceğine işaret etmektedir. Daha da mühim olan Herodotos'un bu sözlerin hemen ardından kendi yorumunu ekleyip Sandanis'i doğrulamasıdır: "Gerçekten de Perslerin Lydialılarl yenmeden önce bir tek lüksleri ve iyi bir şeyleri yoktu". Ayrıca Sandanis'in dile getirdiği bu görüşün Tomyris ve Kyros arasında gerçekleşen savaştan sadece on altı yıl öncesi gibi yakın bir zaman dilimine ait olması da dikkat çekicidir. Yine bu bağlamda Tomyris'in yukarıda verdiğimiz Perslere yönelik, " $b u$ zaferi, içtiğiniz zaman sizin de aklınızı başınızdan alan, damarlarınıza indiği ölçüde size kötü sözler söyleten üzüm kazandi" şeklindeki sözleri de, Herodotos'un ilk başta belirttiğimiz Perslerin şarap karşısındaki incelikli durumlarına dair gözlemlerine şüpheyle bakmamıza yol açmakta ve şaraba dayanıklılıkları ya da köklü bir içki kültürüne sahip olmaları gibi nedenlerle 
bu tuzağa düşenlerin Persler olamayacağı, dolayısıyla Polyainos'un aktardığı bilginin bu bakımdan hatalı olabileceği şeklinde bir düşünceye yönelmek doğru görünmemektedir.

Buna karşılık, İskitlerin şarapla ilgili göreneklerine göz attığımızda yine karşımıza Herodotos'un aktardığı bazı önemli bilgiler çıkmaktadır. Bunları şöyle sıralayabiliriz: İskitler savaş esirlerini kurban ettikleri sırada ritüel gereği şarabı bunların başlarına dökerler (törenin ayrıntıları için bk. Hdt. IV. 62); valiler yılda bir, kendi bölgelerinde suyla şarabı bir krateros içinde karıştırırlar, savaşta bir düşmanı alt etmiş olan her İskit gelip bundan içer, fakat böyle bir başarı elde edemeyenler bu onur şarabından içemezler. Çok sayıda düşman öldürmüş olanlar ise iki kupayla gelir ve üst üste içerler (Hdt. IV. 66). Şarap ayrıca İskitlerin yemin törenlerinde de kullanılır. İskitler toprak bir kabın içine şarap doldururlar, yemin edecek kişiler buna ayrıca kendi kanlarını da karıştırırlar, sonra kabın içine bir pala, oklar, bir balta ve mızrak daldırılır. Bundan sonra tanrısal öfke adına yemin ederler ve kaptaki şaraptan az miktarda içerler, orada bulunanlardan ileri gelenler de bunlarla beraber içerler (Hdt. IV. 70). Herodotos'un bu anlatımlarında İskitlerin şarapla olan ilişkileri daha ziyade insan kurbanı, savaşta gösterilen başarının kutsanması veya yemin törenleri gibi ritüellerle bağlantılı görünmekte olup, tarihçi bu içkinin İskitlerdeki "günlük kullanımı" hakkında bilgi vermemektedir. Buna karşıllk Hippokrates'in İskitleri şişman, tembel ve vakitlerinin çoğunu şarap içerek geçiren kimseler olarak gösteren anlatımlarının dışında ayrıca İskitlerin Hellenlerden dokuma ürünleri ve zeytinyağının yanı sıra şarap ithal ettiklerine dair arkeolojik kanıtlar da vardır (Memiş 2005, 72, 109; Rolle 1980, 100101; Grakov 2006, 18). Ayrıca İskitlerin şaraba kısa zamanda alıştıkları, içkiye olan düşkünlüklerine ve "gürültülü içki âlemlerine" Hellenlerin aşina oldukları, şarabı sulandırmadan içtikleri ve antik yazarlarda şarabın bu tarz içilmesinin "ískit tarzı" olarak adlandırıldığı da bilinmektedir (Grakov 2006, 110-111). Nitekim MÖ VI. yüzyılın ilk yarısında yaşamış olan ünlü lyrik şair Anakreon'un şu sözleri de günlük yaşamda İskitlerin şarabı nasıl içtiklerini açıklayıcı niteliktedir: "Gelin, bırakalım bir yana İskitler gibi gürültü patırtıyla içmeyi, güzel şarkılarla sakince bulalım kafayı" (Anakr. III. 76. İskitlerde şarap tüketimi ve ithali ile ilgili daha detaylı bilgi için bk. Rolle 1980, 101; Durmuş 1993, 90; Schiltz 1994, 126 vd.; Grakov 2006, 97-98; Hellen filozoflarının ölçüsüz içmeye dair görüşleri için bk. Ünsal 1997, 40; Cluzeau 2013, 74). Bu noktada, yabanc1 toplumlara ait ilginç etnografik bilgileri tarihsel amaçlı olarak bolca kullanan (Sauter 2000, 132-133) ve bunları bilhassa Hellenlere tanıtmayı amaç edinmiş olan, bu bağlamda İskitler için de elimizdeki en önemli kaynağımız durumundaki Herodotos'un, onların günlük hayatında şarabın yaygın kullanımından bahsetmemiş olması dikkat çekicidir. Bunun da sebebi aslında yine tarihçinin İskitlerle ilgili anlatımının daha en başında verdiği bir detayda yatmaktadır. Buna göre İskitlerin "esas içkileri” şarap değil kısrak sütünden elde ettikleri bir içecektir. Şüphesiz bu, Orta Asya'da günümüzde de tüketilen hafif alkollü bir içecek olan kımızdır (Hdt. I. 216, IV. 2). Dolayısıyla İskitlerin günlük hayatlarında aslında bu sütten yapılma hafif içkiyi yaygın olarak tükettiklerini, yani şaraba fazla dayanıklı olmadıklarını söylemek mümkündür. Belki de yukarıda değindiğimiz gürültülü şarap eğlencelerinin sebebi biraz da burada yatmaktadır. Nitekim Iustinus'un İskitlerde şarap tüketimi konusunda verdiği küçük fakat önemli bir detayda bunu destekler niteliktedir. Yazara göre İskitler "şaraba alışkın olmadıkları için" sarhoş olmuşlar ve bu yüzden Perslerin gece baskınında yenilgiye uğramışlardır (Iust. I. 8). Iustinus'un verdiği bu bilgi aslında İskitlerin asıl içeceklerinin kısrak sütü olduğunu vurgulayan Herodotos'un anlatımıyla da uyuşmakta ve onların günlük hayatlarında şarabı çok kullanmadıklarına işaret etmektedir. Benzer şekilde Tomyris'in, oğlunu şaraplı tuzak neticesinde esir vermesinden sonra Kyros'a söylediği öfke dolu sözlerin arasında şarapla ilgili olanlar da bu bakımdan dikkat çekicidir. Nitekim Gera da, Massagetlerin bu içkiye alışkın olmadıklarını belirterek Tomyris'in şarabı tanımlamak için kullandığı ifadelerin buna 
işaret ettiğini vurgulamaktadır. Gerçekten de Tomyris, şarabı insanın aklını başından alan ve kötü sözler söyleten bir tür 'zehir' ( $\tau$ ò $\varphi \alpha ́ \rho \mu \alpha \kappa o v)$ olarak tanımlamaktadır (Hdt. I. 212). Bu sözlerinden onun, zarar verici etkilerini bildiği şaraba karşı olumsuz bir tutuma sahip olduğu da anlaşılmaktadır. Gera ayrıca, bu olayı şarap hakkında bilgisi olmayan primitif varlık kyklop Polyphemos'un Odysseus tarafindan kandırılıp alt edilmesi öyküsüne benzeten yorumların da olduğunu belirtmekte, ancak şaraplı tuzağın daha sofistike düşmanlara karşı da sıkça kullanıldığına değinmektedir (Gera 1997, 196 dn. 33 ve 34).

Bu bağlamda Herodotos'un birinci kitabında gözümüze çarpan bir başka anlatım, İskitlerin ele aldığımız olaydan epey önce de benzer bir içkili tuzağa kurban gittiklerini göstermesi bakımından ilgi çekicidir. Buna göre Asya, uzun bir süre İskitlerin boyunduruğu altında kaldıktan ve yağmalandıktan sonra bunların bir kısmı Kyaksares'e ve Medlere konuk olmuşlar fakat "sarhoş edilip" boğazlanmışlardır (Hdt. I. 106; Durmuş 1993, 67-68). Konuyla ilgili yine oldukça ilginç bir başka bilgi de Strabon'da yer almaktadır. Ona göre Kyros bir keresinde Sakalara karşı sefere çıkmış ve ilk başta yenilip kaçmak zorunda kalmıştır. Fakat hemen ardından ordugâhını bol miktarda şarap ve yiyecekle terk ederek uygun bir mesafeye çekilmiş, bunun üzerine Sakalar gelip hazır şöleni görerek kendilerinden geçinceye kadar yiyip içmişlerdir. Öyle ki, Kyros ordusuyla beraber baskına geldiğinde bunların bir kısmını uyurken, bir kısmını da şarap yüzünden kendilerini kaybetmiş vaziyetteyken yakalamış ve neredeyse hepsini kılıçtan geçirmiştir (Strab. XI. 8. 5; ayrıca krş. Duncker 1853, 576). Massagetlerle Sakalar arasındaki yakınlık bilindiğinden, bu anlatım onların içki karşısındaki durumlarını ve böyle bir tuzağa aldanma olasılıklarını güçlendirmesi bakımından önemlidir (Hermann 1920, 1787, 5156; Durmuş 2008, 8, 22, 42, 51). Sonuç olarak söz konusu şaraplı tuzağa gerçekte kimin düşmüş olabileceğini her iki toplumun "şarap kültürleri" bakımından ele aldığımızda aslında iki tarafta da bazı olumsuzlukların olduğunu görmekteyiz. Dolayısıyla Herodotos ve Iustinus'u ya da bunların tam aksi yönde bilgi veren Polyainos'u bu açıdan kesin bir şekilde çürütebilmek ya da doğrulayabilmek zor görünmektedir. Ancak, İskitlerin geleneksel içkilerinin kımız olması ve Iustinus'un İskitlerin şarap içmeye alışkın olmadıklarına ilişkin açık ifadesi; Sandanis'in aksi yöndeki iddiasına rağmen Perslerdeki şarap kültürünün inceliklerine dair Herodotos'un sözleri ve İskitlerin daha önce Medler döneminde de sarhoş edilerek katledildiklerine dair anlatımı; ayrıca şarabı sek içmeyi ve gürültülü patırtılı içki eğlencelerini (Grakov 2006, 111) sevdiklerine dair bilgiler ve Strabon'un Sakalarla ilgili anlatımları kesin birer kanıt olmamakla beraber, kanımızca içkili bir tuzağa düşme olasılığında dikkatleri İskitlere doğru çevirmekte, dolayısıyla bunlar Polyainos'un hatalı bilgi verdiğini düşündüren ilk ipuçları olarak göze çarpmaktadır. Daha önce değindiğimiz üzere, bu konuyla ilgili olarak pek çok araştırmacı da Herodotos'ta anlatılan öyküde olduğu gibi tuzağa düşenlerin İskitler olduğunu kabul etmektedirler.

Yine düşünülmesi gereken diğer bir konu, şarabın yanı sıra bolca yemeğin de kullanıldığı bu tuzağın İskit ve Pers ordusunun "yiyecek ihtiyaçları" açısından bir etki uyandırmış olup olmad1ğıdır. Burada ilk akla gelen şey, İskitlerin sıkça uyguladıkları geri çekilip yiyecek ve su kaynaklarını yok ederek düşmanı açlığa-susuzluğa mahkûm etmek şeklindeki savaş taktiğidir (Hdt. IV. 46; 97; 120-122; 126-127; 131; Memiş 2005, 70-71; Durmuş 2008, 43-44). Bu nedenle, yabanc1 topraklarda ilerleyen Pers ordusunun İskitler karşısında dezavantajlı konumda olduğu ve erzak sıkıntısından dolayı böyle cazip bir tuzağa düşmüş olabileceği, dolayısıyla Polyainos'un söylediği gibi bu tuzağı gerçekten İskitlerin kurmuş olması ilk bakışta ihtimal dâhilinde görülebilir. Ancak gerek Herodotos gerekse Iustinus'a göre bu olay Persler Arakses Nehri'ni geçtikten çok kısa süre sonra - Herodotos'a göre bir gün sonra - gerçekleşmiştir (Hdt. I. 211; Iust. I. 8. krş. Duncker 1853, 574; Hermann 1930, 2128, 19). Yani Pers ordusunda erzak sıkıntısının baş göstereceği uzun bir zaman dilimi söz konusu olmadığından bu seçenek 
kendiliğinden elenmektedir. Buna karşılık İskitlerin bir erzak sıkıntısı içinde olabileceğini ve bu nedenle Perslerin bıraktığı yiyeceklere bu yüzden saldırdıklarını düşünmek de doğru değildir. Zira İskitlerin rahatça erzak temin edebilecekleri kendi yurtlarında olmaları bir yana, planlı geri çekilmeleri sırasında erzaklarını her zaman hazır ettikleri bilinmektedir (Hdt. IV. 121). O halde İskitlerin bu tuzağa düşmüş olmalarında bolca yemeğin kullanılmasının bir başka açıdan etkisi olmuş olabilir miydi? Herodotos bunu, tuzaktan önce Kroisos'un İskitler için söylediği şu sözlerle kendince açıklığa kavuşturmaktadır “... ya büsbütün yanılıyorum ya da onlar bu kadar güzel şeyi bir arada görünce üstüne atılacaklar..." (Hdt. I. 207). Buna benzer bir başka anlatım da 4. kitapta yer almaktadır. Buna göre Kyros'tan bir süre sonra Dareios da İskitlere karşı sefere çıkmak için hazırlık yaparken, Artabanos ilkel ve "yoksul" toplumlardan oluşan İskitlere karşı sefere çıkmaması konusunda onu uyarır, Herodotos da bu öğütlerin doğru olduğunu belirtir (Hdt. IV. 83). Bu anlatımlar dikkate alınırsa İskitlerin yoksulluk çektikleri ve göçebe olmaları sebebiyle çeşit bakımından zengin yiyecekleri bir arada görmeye alışkın olmadıkları, bu nedenle de böyle bir iştah açıcı tuzağa aldanmış olabilecekleri düşünülebilir. Ancak bu bilgiler de durumu açıklamak için yeterli değildir, zira Lydialı Sandanis'in sözlerini hatırlarsak, bu olaya yakın bir dönemde Persler de oldukça yokluk içindeydiler ve "istedikleri kadar değil, ancak buldukları kadar" yemek yiyebiliyorlardı, ayrıca Herodotos'a (I. 71) göre, Lydialıları yenmeden önce bir tek lüksleri ve iyi bir şeyleri de yoktu. Kısacası her iki tarafin da böyle cazip bir yemekli-içkili tuzağa aldanma olasılığı bu bakımdan birbirine yakın görünmektedir. Ayrıca ne Perslerin ne de İskitlerin erzak sıkıntısı veya açlık nedeniyle bu tuzağa düşmüş olduklarını kanıtlayacak kesin bir veri de bulunmadığından Herodotos ve Iustinus'a tamamen zit bir bilgi aktaran Polyainos'un anlatımını bu açıdan bir sonuca ulaştırmak mümkün görünmemektedir.

Ancak bu noktada Herodotos'ta yer alan ve Polyainos'unkine biraz yakın görünen küçük bir detaya değinmeden geçemeyeceğiz. Burada Herodotos, Dareios'un İskit seferini anlatırken İskitlerin uyguladığ 1 bir savaş taktiğinden bahseder. Buna göre İskitler Perslerin "yemeğe oturdukları zamanları" kollayıp bu anlarda baskınlar vermeye ve ellerinden geldiğince Persleri tedirgin etmeye çalışmışlardır (Hdt. IV. 128). Elbette tuzak amacıyla düşmana bir ordugâhta yemek bırakmakla bu taktik arasında fark olsa da, İskitlerin özellikle düşmanın "yemek yediği saatleri” baskın amaçlı kullanmalarıyla Polyainos'ta anlatıldığı gibi yemekten sonra tıka basa doymuş haldeki Perslere baskın vermeleri arasında bir paralellik kurulabilir. Fakat bu da Polyainos'un neden Herodotos gibi önemli bir kaynağa tümüyle ters düştüğünü anlayabilmemiz için yeterli değildir. Ancak yazarın, İskitlerin düşmana saldırmak için yemek saatlerini kolladığı bu tür bir anlatımdan etkilendiğini ve kendince bu olaya uyarlamış olabileceğini bir ihtimal olarak göz önünde tutmak gerekir.

Polyainos tarafindan Tomyris'in; Herodotos ve Iustinus gibi antik yazarlar tarafindan ise Kyros'un kurduğu söylenen bu tuzağın gerçekte kime ait olabileceğine dair gözlemlerimize devam ettiğimizde, MÖ VI. yüzyılın ikinci yarısında büyük bir askerî güce ulaşmış olan Perslerin, İskitleri yenilgiye uğratmak için bu tür bir tuzak kurmaya hiç ihtiyaçları olmadığı, buna karşılık son derece savaşçı, cesur ve atak bir kavim olmalarına rağmen güç bakımından Perslere denk olmayan İskitlerin ise doğal olarak böyle bir tuzak kurma yoluna gittiği, bu bağlamda Polyainos'un anlatımında bir doğruluk payı olabileceği şeklinde bir görüş de ortaya atılabilir. Gerçekten de, daha sonra gerçekleşen Dareios'un seferi sırasında İskitlerin kendi güçlerini Perslere denk görmeyerek çözüm yolları aradıkları ve sonunda geri çekilme taktiğine başvurdukları bilinmektedir (Durmuş 1993, 71; Memiş 2005, 49-50). Ancak, Herodotos'un eserine dikkatlice göz atıldığında İskitlerin Perslerden değil, Perslerin İskitlerden oldukça çekindiklerine dair bulgular fark edilecektir. Nitekim Dareios'un seferi sırasında Pers ordusunda görev alan bir Mytilenelinin, Perslerin İskitlere yenileceğini düşünmediğini söylemesine 
rağmen, hemen öncesinde "onları yenemezsek o zaman sakince yurtlarımıza dönebiliriz" şeklinde bir ifade kullanması zafer kazanma konusunda bir şüphenin mevcut olduğuna işaret etmektedir (Hdt. IV. 97). Bu sefer sırasında İskitler belki her zaman uyguladıkları taktik gereği, belki de denk kuvvetlere sahip olmadıklarından Perslerin karşısına çıkmamışlar ve Dareios'u bıktırana kadar sürekli geri çekilmişlerdir (Hdt. IV. 83 vd. Ayrıca bk. Durmuş 1993, 70-72; Memiş 2005, 48-53). Hatta Dareios bir yerden sonra İskit kralına haberci göndererek artık kaçmaktan vazgeçmelerini söyleyerek oldukça aşağılayıcı ifadeler kullanmıştır. Fakat İskit kralının, kimseden korkmadığını ve kimsenin onu kaçmaya zorlayamayacağını, koruyacak bir kentleri olmadığı için çarpışmaya gerek duymadığını, fakat atalarının mezarlarına saldırırlarsa o zaman savaşmayı göstereceklerini söylemesi, İskitlerin güçlü Pers ordusu karşısında kendilerine duydukları güvene işaret etmektedir (Hdt. IV. 126-127; Memiş 2005, 51). Herodotos, konumuzu teşkil eden Kyros'un seferine dair de benzer nitelikli iki anekdot aktarmakta ve bunlar da İskitlerin Persler için hiç de kolay lokma olmadığını göstermektedir. Nitekim Lydialı Kroisos sefere çıkmadan önce Kyros'a ögütler verirken şunları söyler: "Yenilirsen hem savaşı hem de bütün imparatorluğu kaybetmiş olursun; Massagetler savaşı kazanırsa geri dönmezler... krallı̆̆ına karşı sefere devam ederler" (Hdt. I. 207). Kroisos'un bu sözleri Persler arasında Massagetlere karşı belirgin bir çekincenin varlı̆̆ını ve savaşı kaybetme olasılığının göz ardı edilmediğini açıkça ortaya koymaktadır. İskitlerin Persler karşısında yabana atılır bir güçleri olmadığını gösteren bir diğer önemli örnek de daha önce değindiğimiz, Tomyris'in bu tuzak sonrasında Kyros'a ilettiği sözlerdir. Hatırlanacağı üzere Tomyris Kyros'un bu savaşı ancak hilebazlıkla kazandığını, bunun güçlerin boy ölçüştüğü bir savaş olmadığını ve Massaget ordusunun ancak üçte birini yenebildiğini söyleyerek geri çekilmezse onu kana doyuracağını söylemiştir. Tomyris'in bu sözleri İskitlerin "dürüstçe" gerçekleşecek bir meydan savaşında Persleri yeneceklerinden emin olduklarına işaret etmektedir. Nitekim Massagetler sonradan tam da böyle bir savaşta onları ağır bir yenilgiye uğratırlar. Bu bağlamda ünlü tarihçi Thukydides'in (II. 97), İskitlerin askerî anlamda sahip oldukları büyük gücü dile getiren şu sözlerini hatırlamak yerinde olacaktır: "Asya'da bile hepsi birleşmiş halde hareket edecek İskitlere karşı durabilecek bir kavim yoktur". Durmuş (1993, 8-9) da İskitlerin askerî bakımdan güçlerini sadece Thukydides'ten öğrenmediğimizi, başka kaynaklarda da bundan bahsedildiğini ve şayet İskitler bu güce sahip olmasalardı birçok kavmin yerinden oynamasına veya ortadan kalkmasına yol açamayacaklarını dile getirmektedir (İskitlerin savaş sanatı ve ordu teşkilatı için ayrıca bk. Memiş 2005, 62-71; Hasanov 2009, 10-12). O halde, çok güçlü bir orduya sahip olan Kyros'un değil de daha güçsüz durumdaki İskitlerin böyle bir tuzak kurmaya ihtiyaçları olduğuna, dolayısıyla bu hileyi Tomyris'e mal eden Polyainos'un haklı olabileceğine yönelik bir yorum gerçekçi olmayacaktır. Yine bu bağlamda, savaştan önce Kroisos'un Kyros'a uyarı mahiyetinde söylediği şu sözlerin de dikkate alınması gerekir: "Bir de bırak bütün bu söylediklerimi, ayıp olur, dayanılmaz olur Kambyses oğlu Kyros'un bir kadın önünde geri basıp ülkesinden bir parçayı ona bırakması" (Hdt. I. 207). Büyük olasılıkla Kroisos'un bu sözleri, zaten İskitlerden çekinen Kyros'u daha da tedirgin etmiş ve bu nedenle girişeceği savaşta "bir kadına karşı" yenilgiyi tatmaktansa zaferi garantilemek için böyle bir hileye başvurmasında etkili olmuştur.

Diğer yandan her iki tarafin da beklenen büyük çarpışma nedeniyle son derece dikkatli olması gereken bir zamanda, cazip fakat bir o kadar da şüphe uyandıran bu tuzağa aldanabilen bir ordunun disiplin ve düzen bakımından da sorgulanması gerekir. Bu bağlamda, bir tarafta düzenli bir ordu teşkilatına sahip olan ve Kyros'un önderliğinde Pers egemenliğinin batıda Ege kıyılarına, güneyde Mısır'a kadar uzanmasında rol oynamış büyük Pers ordusu (Diod. II. 44); diğer tarafta ise, süvarileri ve okçularıyla nam salmış cesur savaşçılar olmakla beraber Herodotos'un (IV. 46, 97, 121, 127) da vurguladığı gibi, kentleri ve ekili toprakları olmayan, savaşlarda 
sıkça uyguladıkları geri çekilme taktiğine bağlı olarak hayvanlarını ve ailelerini de yanlarında götüren, yük arabalarını evleri gibi kullanan, dolayısıyla planlı hareket eden düzenli bir ordudan ziyade anlık gelişmelere göre hareket eden göçebe bir topluluk bulunmaktadır (ayrıca bk. Durmuş 1993, 7, 89-90, 151; Sauter 2000, 135; Memiş 2005, 71, 74; Hasanov 2009, 13). Nitekim daha sonraları Dareios'un İskit seferi sırasında gerçekleşen bir olay da İskitlerin ordu disipliniyle ilgili bir ipucu sunması bakımından ilgi çekicidir. Buna göre, İskitler artık geri çekilmeyi bırakıp Perslerin karşısında savaş düzeni aldıkları bir sırada, savaşçılar birdenbire önlerinden geçen bir 'tavşanın' peşine takılıp naralar eşliğinde saflarını bozmuşlar ve savaşı bırakıp tavşan avına başlamışlardır (Hdt. IV. 134 krş. Gera 1997, 191). Dareios bu davranışı İskitlerin onları umursamayışı olarak yorumlamıştır. Fakat bu olay aynı zamanda İskit savaşçılarının atılganlıklarının bir sonucu olarak kimi zaman başlarına buyruk olabildiklerine ve savaş disiplininden kopabildiklerine işaret etmesi bakımından önemli bir ipucudur. Bu bağlamda, incelediğimiz şaraplı-yemekli tuzağa geri dönersek, İskit savaş̧̧ılarının yukarıdaki olaya benzer şekilde 'anlık gelişen' bir düzensizlik örneği sergileyerek terk edilen ordugâhta kendilerinden geçinceye kadar yiyip içmiş olmaları, Pers ordusunun böyle bir tuzağa düşmüş olmasından daha güçlü bir olasıl1k gibi görünmektedir. Fakat İskitlerin yakınlardaki büyük düşman tehlikesini nasıl göz ardı edip de kendilerine böyle bir ziyafet çektikleri konusu elbette düşündürücüdür. Belki de bunun yanıtı onların yukarıda değindiğimiz karakteristik özelliklerinde yatmaktadır. Muhtemelen, göçebe bir hayatın sertleştirdiği bu insanların cesaret ve atılganlıkları kendi yurtlarında oluşlarının verdiği öz güvenle birleşmiş ve bunun sonucunda Pers ordusunun büyük gücünü küçümsemişlerdi. Buna karşılık, disiplinli bir ordu olmaları bir yana, bilmedikleri düşman topraklarında ilerleyen ve çok dikkatli olmaları gereken Perslerin böyle bir zamanda daha ilk başta şüphe uyand1ran bu tür bir içkili ziyafete kendilerinden geçecek kadar kapılmış olmaları bizce uzak bir ihtimaldir. Dolayısıyla Polyainos'un Persleri bu tuzağa düşüren kişi olarak Tomyris'i gösteren sözlerini doğru kabul etmek bu açıdan da mümkün görünmemektedir.

$\mathrm{Bu}$ bağlamda kanımızca bir başka önemli ipucuna da, yukarıda değindiğimiz İskit savaşçılarının saflarını bozmasıyla ilgili hadiseden hemen sonra rastlamaktayız. Buna göre, İskitlerin umursamaz davranışları nedeniyle Gobyras, Pers kralına gece olduğunda ordugâhta ateşler yakmayı ve askerlerin işe yaramaz olanlarını bir bahaneyle geride bırakıp oradan ayrılmayı teklif eder. Geride kalanlara da, sonradan Dareios güçlü askerlerle İskitlere saldırdığı sırada onların kampı koruyacakları söylenir ve Pers ordusu bu sayede kayıp vermeden geri çekilir (Hdt. IV. 134-135 krş. I. 207, 211). Şüphesiz Kyros ile Dareios'un taktikleri arasında uygulama bakımından önemli bir farklılık vardır. Zira Kyros'un seferi sırasında Persler önce geri çekilir gibi yaparak ordugâhı terk etmiş fakat İskitler gelince onlara baskın vermişlerdir; Dareios'un olayında ise Persler ordugâhı yine bırakmış ancak bu sefer geri dönmeyerek tümüyle çekilmişlerdir. Fakat bu farklılığa rağmen bir miktar işe yaramaz askerle beraber "ordugâhı geride bırakmak" her iki stratejideki temel benzerlik olarak göze çarpmaktadır. Diğer yandan Herodotos'ta Massagetlere karşı uygulandığı söylenen şarap ve yiyecekle donatılmış ordugâhı düşmana bırakma taktiğinin Strabon'a (XI. 8. 5) göre, bir defasında yine Kyros tarafından Sakalara karş1 kullanılmış olması ayrıca dikkat çekicidir (Duncker 1853, 576). Ancak daha önce değindiğimiz gibi bu olayın sonradan Massagetlere "uyarlanmış" olabileceğine dair Duncker'in görüşünü de göz ardı etmemek gerekir. Bu ipuçları, söz konusu taktiğin Perslerce bilinen bir uygulama olduğunu ve Dareios'un da, önceden Kyros tarafından uygulanan bu taktikten esinlenmiş olabileceğini düşündürmekte, dolayısıyla olayımızla ilgili olarak Polyainos'un aksine Herodotos'un ve ona benzer anlatımların dikkate alınması gerektiği yönündeki görüşümüze katkı sağlamaktadır.

Son olarak, bu olay sırasında dönemin en güçlü ve askerî anlamda en yetenekli krallarından olan Kyros'un orduya 'bizzat' komuta ediyor olması kanımızca Polyainos tarafindan aktarılan 
bilginin doğruluğundan şüphe etmek açısından çok önemli bir başka husustur. Nitekim, Polyainos (VIII. 28) ile tam aksi yönde bilgi vermelerine rağmen Herodotos (I. 211) ve Iustinus (I. 8) da Kyros'un bu olay sırasında Pers ordusunun başında olduğunu bildirmektedirler. Kyros'tan övgüyle söz eden Diodoros (II. 44) ile savaşlarda talihin hep ondan yana olduğunu ve düşmanların ona boyun eğmekten başka bir şey yapamadıklarını söyleyen Herodotos'u (I. 204) Pers kralının üstün vasıflarına değinen antik yazarlara örnek göstermek mümkündür (ayrıca bk. Gera 1997, 187). Keza, Kyros'un gerek bir kral gerekse komutan olarak olumlu yönlerine çokça yer veren Duncker'in $(1853,581)$ yanı sıra Wiesehöfer $(1999,1018)$ de, 'askerî dehas1' ve izlediği tatlı sert politikalarıyla Kyros'un o dönemde kapsam ve tarihsel önem bakımından eşi benzeri olmayan bir dünya imparatorluğu yarattığını vurgular. Şüphesiz bununla bağlantılı diğer bir önemli konu da, içki ve yemeğe kapıldıkları esnada İskitlerin başında Tomyris'in değil 'savaş tecrübesi olmayan' genç oğlunun bulunduğunu belirten Iustinus'un açık ifadesidir. Bu aktarım aynı zamanda Herodotos'unkiyle de örtüşmektedir. Zira Herodotos Tomyris'in oğlu Spargapises'in 'tecrübesizliğinden' söz etmese bile, o da Pers baskını sırasında İskitlerin başında Tomyris'in yerine oğlunun bulunduğunu söylemektedir. Ayrıca Iustinus, Tomyris'in oğlundan söz ederken, oraya geliş amacının savaşmak değil de sanki bir şölene katılmak olduğunu ve düşmanları hesaba katmadan adamlarının şarapla kendinden geçmesine sebep olduğunu söyleyerek onu eleştirmektedir (Iust. I. 8). Bu anlatım, bizzat Kyros'un komuta ettiği Perslerden ziyade, fazla savaş deneyimi olmayan bir gencin idaresindeki İskitlerin tuzağa aldanma ihtimalini güçlendiren önemli bir bulgu niteliğinde olup, Polyainos'un bu konuda hatalı bilgi aktardığına yönelik görüşümüzü desteklemektedir. Zira uzun yıllar boyunca Pers ordusuna pek çok başarı kazandıran Kyros'un, düşman topraklarında ve İskitlerin her an saldırabileceği tehlikeli bir ortamda şarap ve yemekle cezbedici hale getirilip şüpheli bir biçimde terk edilmiş bir ordugâhta hem kendisinin hem de askerlerinin savaşamayacak duruma düşmesine sebep olmuş olması bizce inandırıcı değildir.

Sonuç olarak Polyainos'un anlatımını değerlendirdiğimizde, Tomyris'i Massagetlerin başında göstermesi, Kyros'un onun topraklarına girmesi, iki ordunun çarpışması ve sonunda Tomyris'in galip gelerek Kyros'u öldürmesi gibi genel nitelikli bilgilerin Herodotos ile örtüştüğü anlaşılmaktadır. Buna karşılık Polyainos, şarap ve yemekli taktikle ilgili Herodotos ve Iustinus'un tam aksi yönde bir bilgi verdiğinden doğal olarak Kroisos'un bu tuzağ kurmak için verdiği öğütlere, Tomyris'in oğlunun İskitlerin başında oluşuna, Persler tarafından esir alınmasına, sonradan intihar etmesine ve Tomyris'in Kyros'u aşağılayan sözlerine hiç değinmemektedir. Ayrıca Polyainos'a bakıldığında Persler bir tek savaşta mağlup olmuş görünmektedirler. Hâlbuki Herodotos, Perslerin önce galip geldiğini ve daha sonra gerçekleşen "ikinci bir savaşta" yenildiklerini anlatmaktadır (Iustinus'ta da benzer bir durum söz konusudur). Bütün bunlar Polyainos'un Herodotos'tan farklı anlatımlar sunan ve Tomyris'e ait olan taktiklerden söz eden başka antik yazarlardan esinlenmiş olabileceğini düşündürmektedir. Bu bakımdan Polyainos'tan farklı da olsa, Iustinus ve Frontinus'un Tomyris tarafindan uygulanan bir taktikten söz etmeleri dikkat çekicidir. Nitekim Iustinus, Perslerin uyguladığı şarap-yemek hilesinin yanı sıra Tomyris' in dağlara çekilip pusuya düşürme taktiğinden söz eder. Frontinus ise, yalnızca bu ikincisine değinir. Frontinus ile Polyainos arasındaki benzer taraf belki de Tomyris'in "kaçar gibi yaparken geri dönerek" Persleri yenilgiye uğratma sahnesidir. Ziegler'in görüşünü hatırlarsak, Frontinus'un şarap-yemek tuzağını göz ardı etmesinde muhtemelen Kyros'u hilebaz birisi olarak göstermeme gayretinin payı olduğunu söylemek mümkündür. Diğer yandan Diodoros (II. 44) ise ne Persler ne de "Iskitler" tarafindan uygulanan herhangi bir taktikten söz eder (ayrıca bk. Frontin. II. 5. 5).

Bu bağlamda, Polyainos ile ilgili önemli araştırmacılardan Melber'in görüşleri fayda sağ- 
layabilir. Melber, söz konusu olayın antikçağda iyi bilindiğini ve Ktesias dışında pek çok tarih yazarının Herodotos'tan etkilendiğini belirtir. Duncker'e göre bu öykünün bazı farklılıklar içermekle beraber Pompeius Trogus'a da temel teşkil ettiğini; ayrıca Polyainos için de böyle bir durumun söz konusu olduğunu, fakat onda bu hikâyenin Herodotos'ta anlatılanın tam tersine çevrildiğini ve Kyros'un ölümünün doğrudan bu olaya bağlandığını belirten Melber, bunun Polyainos'a özgü değil, kahramanların yer değiştirmesinden ibaret bir anlatım olduğunu vurgular. Ayrıca bu durumun, iyi bilinen bu öyküyü Polyainos'un hatırladığı gibi yazmış olmasından kaynaklandığ1 görüşüne de karşı çıkmaktadır. Melber'e $(1885,477)$ göre, Polyainos'un kitabında rastlanan hatalı aktarımlara genellikle yararlandığı derleme eserlerin sebep olduğu bilindiğinden burada da olasılıkla böyle bir durum söz konusudur ve yazar Herodotos yerine bu tür bir kaynaktan faydalanmış olmalıdır. Bu durumda Polyainos'un iyi bilinen bu öyküyü anlatan önemli yazarları yeterince incelemeden, bu tür bir derleme eserde rastladığı bilgileri özensizce kullandığ1 (yazarın bu yönü için bk. Kroh 1972, 507) ve olay hakkında da önceden fazla bir bilgisi olmadığı düşünülebilir.

Ancak bu noktada kanımızca bir başka olasılığın daha göz ardı edilmemesi gerekir. Bu da Polyainos'un Herodotos'ta anlatılan bu olayı aslında bildiği, fakat iki sebepten dolayı kasıtlı olarak değiştirmiş olma ihtimalidir. Bunlardan ilki, eserinin ilgili kısmında farklı kökenlerden çok sayıda cesur kadının etkileyici yaşam öykülerinden kesitler sunan yazarın çok ilgi uyandıracak bir ilave yapmak adına Herodotos'ta anlatılan bu olayı dönüştürüp Tomyris'e uyarlamış olmasıdır. Yazar bunu yaparken belki de Iustinus ve Frontinus gibi yazarlarda anlatılan Tomyris'in dağlık alana çekilip Kyros'u tuzağa düşürmesiyle Herodotos'taki Pers tuzağını harmanlamıştır. Diğer olasılık ise, Polyainos'taki anlatımın Herodotos'un verdiği bilgilerin tersine çevrilmiş halinden ibaret olduğunu belirten Ziegler'in $(1937,1703,8$ ve 1704, 31) de ileri sürdüğü gibi "Herodotos dışındaki” yazarların Kyros'un şöhretine leke sürmemek adına onu bir barbar tuzağına düşmüş gösterme gayretlerine benzer bir amaçla Polyainos'un da bu olayı Tomyris'e kurgulamış olmasıdır. Nitekim Meister $(2001,40)$ de, Polyainos'un eserinin tarihsel değer bakımından farklılıklar içerdiğini, zira kısmen doğru, kısmen kurgusal kısmen de güvenilmez olduğunu belirtmektedir. Gerçi Polyainos'un böyle bir çabası olmuşsa bile, yarattığı etki bizce tam aksi yönde gerçekleşmiştir. Zira ona göre Kyros ve ordusu Tomyris'in kurduğu şarapl1-yemekli tuzağa kolayca aldanarak tıka basa yemiş içmiş ve sonra da Massagetler hepsini kıliçtan geçirmiştir. Bu anlatım bizce Persleri ve kralın şanını korumak bir yana, Pers ordusunu böyle bir tuzağa düşecek kadar "berbat" bir sevk ve idare altında göstermekte ve ordunun başındaki Kyros'un şöhretini aslında alaşağı etmektedir. Sonuç olarak Polyainos'un bu olay hakkında hatalı bir bilgi aktarmış olduğunu, artık söyleyebilmekle beraber, neden böyle bir duruma düştügünü ise tam olarak tespit edememekteyiz. Yazarın, faydalandığı kaynaklar hakkında bilgi vermemesi de bu tespiti güçleştirmektedir. Ayrıca, eserini dönemin Roma imparatorlarına ithaf eden ve onlar için askerî açıdan faydalı ve kullanışlı olması amacıyla yazan Polyainos'un, antikitede iyi bilinen (Ziegler 1937, 1704, 6) böyle bir öyküyü kasıtlı olarak değiştirip hem yanlış bilgi vermeyi hem de tarih önünde sorumlu duruma düşmeyi göze alıp almayacağ da ayrı bir tartışma konusu olacağından şimdilik Melber'in bu konudaki yorumu akla daha yakın görünmektedir.

Kyros'un İskit seferi sırasında gerçekleştiği bildirilen diğer savaş taktiği ise Herodotos d1şındaki pek çok antik yazara göre Tomyris tarafından uygulanmış olup, Persler bunun sonucunda bozguna uğratılmış ve Kyros da bu savaşta öldürülmüştür (Duchesne-Guillemin 1979b, 885). İskitlerin sıkça uyguladıkları "geri çekilme" taktiğini yansıtan söz konusu olay hakkında özellikle Iustinus ve Frontinus bilgi vermekte olup, her iki yazarın da anlatımları benzerlik göstermektedir. Iustinus'a göre Tomyris, oğlunun ölümünün ardından kaçıyormuş izlenimi vererek 
dağlık alandaki dar geçitlere doğru geri çekilir ve sonunda dağda kurduğu bir tuzak yardımıyla Pers ordusunu yok eder (Iust. I. 8). Iustinus bu olayı Kyros tarafından uygulanan şarapl1-yemekli tuzak sayesinde Perslerin kazandığ "ilk zaferden sonra" gerçekleşmiş gibi anlatır. Frontinus (II. 5. 5) Persler tarafından kurulan ilk tuzaktan hiç söz etmez, fakat olayın kalan kısmını Iustinus'a benzer biçimde aktarır ve Tomyris'in dağ geçitlerinde "ansızın geri dönüp" arazinin de yardımıyla zaferi elde ettiğini anlatır (Frontinus burada ondan Tamyris olarak söz eder). Diodoros (II. 44) ise, daha önce değindiğimiz gibi bu tuzaktan bahsetmez ve yalnızca Kyros'un ordugâhının ele geçirildiğini söylemekle yetinir.

$\mathrm{Bu}$ yazarlara karşıllk İskitlerle ilgili elimizde bulunan bilgilerin büyük kısmını borçlu olduğumuz Herodotos ise ilginç şekilde Tomyris'in kurmuş olduğu böyle bir tuzaktan hiç söz etmemektedir. Ona göre Tomyris oğlunun ölümünün ardından bütün kuvvetlerini toplamış ve 'doğrudan' Perslerin üzerine yürümüştür. Görünüşe göre büyük bir öfkeye kapılmış olan Tomyris, Persleri yenmek için herhangi bir tuzak kurmaya "lüzum görmemiştir". Bu noktada Ziegler'in daha önce değindiğimiz görüşünü hatırlamak yerinde olacaktır. Ona $(1937,1704,17-36)$ göre bu konu hakkında bilgi veren Herodotos dışındaki antik yazarlar ikinci dereceden ve Pers yanlısı kaynaklar olduğundan, bir meydan savaşında yenilmiş olmanın 'ayıbı' bu yazarlarca Perslerin ve Kyros'un üzerinden alınarak kral barbarca bir tuzağın 'kurbanı' olarak gösterilmektedir. Herodotos'un bu olaya dair elimizdeki en güvenilir kaynak olmasıyla ilgili Ziegler' in görüşüne katılmaktayız. Ayrıca yine onun belirttiği gibi, daha sonraki bazı yazarların Pers kralını tuzağa düşmüş gibi gösterip şöhretini korumaya çalıştıkları da düşünülebilir. Zira bunların, Kyros'un kurduğu ilk tuzaktan ve Tomyris'in bununla ilgili olarak söylediği ağır sözlerden bahsetmeyişleri bunu destekleyici unsurlar olarak görülebilir (Iustinus ise hem Kyros'un hem de Tomyris'in kurduğu tuzaktan söz etmekle bunlardan ayrılmaktadır). Ancak, Herodotos'taki gibi Kyros'un bir meydan savaşında yenilgiye uğramasından bahsetmek yerine Tomyris'in tuzağını anlatmalarını bu doğrultuda değerlendirmek konusunda bazı tereddütlerimiz bulunmaktadır. Zira savaşlarda başarıyla uygulanan taktikler söz konusu olduğunda, tarih önünde aslında bunlara kurban gidenlerin değil başarıyla uygulayanların ön plana çıkacağını, dolayısıyla bir tuzağa düşmüş olmasından söz etmenin Kyros'un şanını korumaktan ziyade onu daha kötü bir duruma sokacağını bu yazarlar tahmin edememişler midir? sorusu akla gelmektedir. Ayrıca bir meydan savaşında komutanlar ordularını en iyi şekilde sevk ve idare etseler bile, anî gelişen olaylara veya askerlerin moral motivasyonuna bağlı olarak da savaş kaybedebilirler. Dolayısıyla Herodotos'un aktardığı böyle 'tuzaksız' kaybedilen bir meydan savaşından bu yazarların bahsetmemesi için aslında geçerli bir sebep bulunmamaktaydı. Neticede Kyros gibi tecrübeli bir kralın bu yazarlarca 'barbarların' tuzağına düşmüş gösterilmesi bizce bir meydan savaşında yenilgiye uğramasından daha kötüdür ve asıl imaj zedeleyici durum budur (benzer bir durum yukarıda değindiğimiz gibi özellikle Polyainos'un anlatımı için geçerlidir). Dolayısıyla bu yazarlar başarıyla uygulanan bir taktikten söz etmekle aslında belki istemeseler de Tomyris'i yüceltmiş olmaktaydılar. Diğer yandan Ziegler'in sözlerinden hareketle, bu yazarların olmayan bir tuzağ gerçekmiş gibi gösterdiklerine yönelik bir sonuç çıkarılmak istenirse buna dair de elde herhangi bir kanıtın olmadığını unutmamak gerekir. Kaldı ki, Kyros'un şaraplı-yemekli tuzakla Massagetleri yendiğini söyleyen Herodotos'un Perslere dair gerçek bir askerî başarıyı naklettiğini kabul ediyorsak, Tomyris'in geri çekilme taktiğiyle Kyros'u bozguna uğrattı̆̆ını anlatan antik yazarların da tecrübeli bir kralın komutasındaki büyük bir orduya karşı İskitlerin kazandığ gerçek bir taktiksel başarıyı ilginç bularak paylaştıklarını düşünmek için de bir engel bulunmamaktadır. Bu bağlamda, hem Kyros'un hem de Tomyris'in kurduğu tuzaktan aynı pasajda söz eden, ayrıca Herodotos'taki pek çok bilgiye de yer veren Iustinus kanımızca elimizdeki en doğru bilgileri aktaran kaynak olarak ön plana çıkmaktadır. Bizce Tomyris, tıpkı onun ve Fron- 
tinus'un söylediği gibi gerçekten İskitlerin en çok başvurdukları bozkır savaş taktiğini uygulamış ve düşmanı olabildiğince kendi topraklarına çekerek sonra da pusuya düşürmüş olmalıdır (İskitlerin uyguladığı bozkır savaş taktiği hakkında bk. Durmuş 1993, 78-79; Memiş 2005, 50, 70-71). Nitekim Hermann (1930, 2128, 47-52) da, Massagetlerin bu savaşta Perslerin dönüş yollarını kestikten sonra onları dağlık bölgedeki uçurumlara doğru çektiklerini ve orada yok ettiklerini düşünmenin doğru olabileceğini belirtmektedir (ayrıca bk. Gera 1997, 197). Aynı şekilde Durmuş $(2008,37)$ da Kyros'un ölümüne neden olan bu savaşın dar bir boğazda gerçekleştiğini ve Sakaların lideri Tomris tarafından uygulanan 'Turan taktiği' veya 'kurt oyunu' adı verilen bozkır savaş taktiğiyle kazanıldığını kabul etmektedir.

Ancak bu olaya kronolojik bakımdan en yakın yazar olan ve ayrıca İskitlere dair en kapsamlı bilgileri aktaran Herodotos'un Tomyris'in bu taktiğinden söz etmemesi oldukça ilgi çekicidir. Bu noktada şöyle bir soru akla gelmektedir: Iustinus ve Frontinus gibi yazarlarca anlatılan bu savaş taktiğini Herodotos acaba kendince bazı sebeplerden dolayı bilerek mi görmezden gelmiştir? Bu bağlamda Herodotos'un anlatımında göze çarpan bazı hususlara değinmek yerinde olacaktır. Hatırlanacağı üzere, tarihçi daha henüz seferin başında Kyros'un Massagetleri şarapl1-yemekli bir tuzağa düşürdüğünden ve bu esnada düşmanın önemli bir kısmının yok edildiğinden söz etmektedir. Ancak burada asıl ilginç olan Herodotos'un olayın hemen ardından Tomyris'in ağzından aktardığı sözlerdir. Zira tarihçi Kyros'un şarap yardımıyla kazandığını, bunun güçlerin boy ölçüştüğü bir savaş olmadığını ve bir tuzakla onları yenebildiğini söyleyerek kralı açıkça aşağılayan, düzenbazlıkla suçlayan ve ardından tehdit eden Tomyris'in sert sözlerine yer vermekle okuyucuda İskitler karşısında Pers kralının ancak hileyle galip gelebileceği hissini uyandırmaktadır. Herodotos'un, bu ağır sözlere karşılık Kyros'un cevabını geçiştirmesi ve herhangi bir yorumda da bulunmayarak âdeta Tomyris'in sözlerini destekliyor gibi görünmesi de bunu pekiştirmektedir (Hdt. I. 212). Zira belki de Kyros savaşta hile yapmanın askerlik sanatıyla bağdaştı̆̆ına ve İskitlerin tuzağa düşmelerinin kendi başarısızlıkları olduğuna dair bir cevap vermiş de olabilirdi. Sonuçta Tomyris bu sert sözlerinin hemen ardından herhangi bir hileye başvurmaksızın gerçekten Persleri büyük bir meydan savaşında (tam da kendisinin dediği gibi güçlerin boy ölçüştüğü bir savaşta) yenilgiye uğratır. Herodotos âdeta olayın başından beri Perslerin İskitler karşısında galip gelmek için tuzak kurmaya ihtiyaçları olduğunu, buna mukabil İskitlerin ise eğer isterlerse bir hileye gerek duymadan onları alt edecek durumda olduklarını okuyucuya hissettirmekte, Tomyris'in sözleriyle de bunu zirveye taşımaktadır. Tarihçinin anlatımındaki genel sıralama da buna tamamen uygundur. Öyle ki Herodotos (I. 205), henüz savaş başlamadan önce Kyros'un Tomyris'e yaptığı evlilik teklifinin bile aslında onun ülkesini ele geçirmek için bir tuzak olduğunu açıkça belirtmektedir. Nitekim bu teklif reddedilince Kyros'un hemen savaş hazırlıklarına başlaması da bunun kanıtıdır. Gera (1997, 189) da, Kyros'un Massaget ülkesini sulh yoluyla ele geçirmeye çalıştı̆̆ını belirterek, Perslerde bu tür evliliklerle başka topraklarda hak iddia etme yönteminin bir tür "çeyiz hakkı" gibi uygulandığını vurgulamaktadır. Bunun ardından da sırasıyla Kroisos İskitleri yenmesi için Kyros'a şarap-yemek hilesini teklif eder, Kyros bunu uygulayarak galip gelir, Tomyris onu hileye başvurduğu için aşağılar, eşit şartlardaki bir savaşta onu yeneceğini söyler ve gerçekten de hilesiz bir savaşta Persleri yok eder. Bu bağlamda, Herodotos'un olayların akışına uygun düşmesi için Tomyris'in kurduğu bu tuzağı bilerek es geçmiş olması bizce büyük bir olasılıktır, zira Kyros'u hile yaptığı için alenen aşağılayan Tomyris benzer şekilde eğer bir hileyle kazanmış gösterilseydi bu durum yazarın okuyucuda uyandırdığı hissiyata hiç uygun düşmeyecekti. Nitekim savaşın sonunda İskit kraliçesinin söylediği şu sözler de ayrıca dikkat çekicidir: "Hayattayım

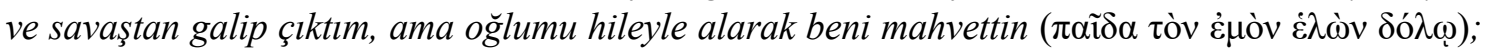
ama ben de söylediğim gibi seni kanla doyuruyorum" (Hdt. I. 214). Görüldüğü gibi Tomyris 
savaştan önce düzenbazlıkla suçladığı yetmezmiş gibi ölümünden sonra bile Kyros'un hilebazl1ğını tekrar dile getirerek kendi zaferinin dürüstçe kazanılmış olduğunu ilan etmekte, bu da metnin akışına tamamen uygun düşmektedir [Gera $(1997,191)$, Herodotos'un okuyucuyu Kyros'un felaketine giden yol konusunda bir başka açıdan da hazırladığını ileri sürmektedir. Zira Herodotos (I. 204), bu olayların daha en başında Kyros'u çok şanslı ve giriştiği her işte başarılı olan, yüce yaradılışlı birisi olarak göstermiştir ki, bu durum Hellenlerin hybris algısına çok uygun düşmekteydi. Okuyucunun gözünde Kyros'un kendine olan bu güveni bir felakete uğramak için artık yeterince olgunlaşmıştı. Nihayetinde de Kyros'un sonu bir kadının elinden olmuş, bu da şüphesiz duruma etkileyici bir görünüm katmıştır: benzer bir görüş için ayrıca bk. Ambühl 2013, 595: yükseliş, hybris ve düşüş]. Dolayısıyla Herodotos'un yansıttığı Tomyris karakteri zafer kazanmak için hile yapmaya tenezzül etmeyecek kadar soylu bir kadın profili çizmekte ve Kyros ile Tomyris arasında taktiksel bakımdan açık bir yöntem farklılığı göze çarpmaktadır. Diğer yandan Gera (1997, 197-198), Herodotos'un aksine savaşı tuzakla kazand1ğından söz eden diğer antik kaynakların Tomyris'in 'değerini' azaltmaya çalıştıklarını ileri sürmektedir. Ona göre bu kaynaklarda Tomyris artık Herodotos'ta gösterildiği gibi asil duruşlu ve mert bir barbar olmaktan ziyade stratejik manevralar yapan düzenbaz bir figür olarak belirmektedir. Aynı bakış açısını Herodotos'a yöneltirsek, bu sefer de hep hileye başvurduğunu anlatmakla Kyros'u düzenbaz göstermek ve değerini azaltmak çabası içinde olup olmadığ 1 sorusu akla gelmektedir. Diğer yandan, daha önce de belirttiğimiz gibi, düşmanı bir hileyle alt etmek savaş koşullarında aslında olağan kabul edilen ve çoğu zaman da zorunluluktan kaynaklanan bir durumdur. Bu nedenle bir muharebeyi hileyle kazanmayı düzenbazlıkla, tersini ise mertlikle ilişkilendirmek doğru değildir. Bilakis akıllıca tuzaklar kurarak düşmanı alt etmeyi başaran bir komutanın askerî açıdan olumlu şekilde değerlendirilmesi beklenir. Bu nedenle söz konusu kaynaklarda Gera'nın belirttiği gibi Tomyris'in kurduğu tuzaktan olumsuz anlamda mı söz edildiğini, yoksa aslında büyük Pers ordusunu akılcı bir yöntemle dize getirmiş bir barbar kadına dikkat çekilmeye mi çalışıldığını belirlemek tartışmaya açık bir konudur.

Başka yazarların söz ettiği bu savaş taktiğine Herodotos'un değinmemiş olmasını bir de Ziegler'in bakış açısıyla değerlendirmek istersek yine benzer bir durumla karşılaşmaktayız. Hatırlanacağı gibi Ziegler, Herodotos dışındaki yazarların Pers yanlısı bir tutumla Kyros'un 'şanını korumak için' onu barbarların tuzağına kurban gitmiş gösterdiklerini ileri sürmüştür. Aynı bakış açısını Herodotos'a yöneltirsek, eserinde İskitlerin gelenek göreneklerine, yaşadıkları coğrafyaya ve savaşçı yönlerine çok geniş yer veren tarihçinin bu yiğit bozkır savaşçılarından etkilendiğini ve bu olayda hem onların hem de Tomyris'in şöhretini korumak ve Persleri dürüstçe gerçekleşen bir meydan savaşında galip gelmiş göstermek için onun kurduğu bu tuzaktan söz etmediğini düşünmek mümkündür. Gerçi ilk bakışta sadece Tomyris'in değil Kyros'un da itibarı korunuyor gibi görünebilir, zira Pers kralının bir tuzağa 'kolayca aldanan' değil de, er meydanında 'mertçe kaybeden' bir komutan gibi gösterildiği düşünülebilir. Ancak bizce tarihçinin böyle bir arzusu olmamıştır, zira yukarıda da değindiğimiz gibi olayın genel akışına bakıldığında Kyros, İskitlere karşı sürekli tuzak kurmaya çalışan, fakat sonunda dürüstçe savaşan Tomyris karşısında kaybetmiş bir kral olarak gösterilmektedir. Ayrıca Gera da, Herodotos'un eseri 1şı̆̆ında Tomyris ile Kyros'u kıyasladığında İskit kraliçesinin Kyros'a göre daha baskın bir karakter olarak yansıtıldığı sonucuna varmaktadır ki, biz de bu görüşe katılmaktayız. Özellikle de Tomyris'in konuşmaları bir elçi aracılığıyla bile olsa tüm canlılığıyla verilirken, Kyros'un hep suskun bırakılması çok dikkat çekicidir. Gerçekten de Tomyris sürekli ögüt veren, uyaran hatta aşağılayan konuşmalar yaparken Kyros'un yanıtlarına yer verilmemekte ve kral âdeta geri plana itilmektedir. Nitekim evlilik teklifinin reddedilmesine, savaş hazırlıkları sırasında Tomyris'in yaptığg uyarılara, sonradan ondan işittiği ağır sözlere karşıllk Kyros'un verdiği 
cevaplar hep belirsizdir. Son olarak da Kyros'un cesedi başında, yine Tomyris'in onu hilecilikle suçlayan sözlerine yer verilmektedir ve bu sefer de Kyros artık bir ölü olduğu için yanıt verememektedir (Gera 1997, 192). Gera'ya göre Herodotos'un anlatımlarında Tomyris, Kyros'tan daha zeki, cesur ve etik değerlere daha bağl1, hatta tuzak kurmadan savaştığı için daha 'erkeksi' bir görünüme sahiptir. Dolayısıyla Herodotos'ta açıkça ön plana çıkarılan kişi bizce de Tomyris olup, bu sebeple tarihçi yansıttığı bu 'mert' karakteri korumak amaciyla onun kurduğu tuzaktan bilerek söz etmemiştir. Benzer şekilde Gera (1997, 197-198), Kyros'un kurduğu şaraplı tuzaktan başka kaynaklarda söz edilmemesini Pers kralını daha olumlu ve dürüst göstermek için kasıtlı olarak göz ardı edilmesiyle bağdaştırmaktadır.

Bu noktada Herodotos'un, Kyros'un ölümü hakkında pek çok şey anlatıldığını, ancak bunların arasından "kendisine en doğru görüneni" seçtiğini belirtmesi de ayrıca önemlidir. Tarihçinin bu sözleri bize bu olayla ilgili kendisine nakledilen bilgiler arasından belirli bir seçim yaptığını göstermekle beraber onun hangi yazarlardan faydalandığını ne yazık ki öğrenememekteyiz (Sancisi-Weerdenburg 1985, 464). Böyle bir seçim farklı anlatımlardan bazılarını tamamen elemek, bazılarını olduğu gibi almak ya da kısmen veya tamamen değiştirmek yani kurgulamak şeklinde de olabilir. Bu bağlamda tarihçi belki de yukarıda değindiğimiz nedenlerden dolayı böyle bir tercih yaparak Tomyris'in taktiğini anlatan yazarların anlatımlarını bilerek es geçmiş veya değiştirmiş olabilir. Benzer şekilde, Pers kralının ölümüyle ilgili çeşitli anlatımlar arasında belki de en korkuncu olan, kafasının kesilerek kan dolu bir çuvala sokulması sahnesini kullanmasını, onun renkli anlatımıyla bağdaştırabileceğimiz gibi, İskitlerin şanına yakışan savaşçı ve acımasız yönlerini iyice vurgulayarak onların bu yöndeki şöhretlerini korumak adına yapılmış bilinçli bir tercih olarak düşünmek mümkündür. Keza büyük bir Pers kralının ölüsüne yapılan bu korkunç muameleyi hiç yorum yapmadan aktarması da hile yüzünden yaşanan bir yenilginin ardından oğlunun kaybına dair Tomyris'in duyduğu "hakll” öfkeyi yansıtmak istediği izlenimini uyandırmaktadır.

Diğer yandan Duncker, MÖ V. yüzyılda İran'da Kyros'un yaşam öyküsüne dair çeşitli halk hikâyelerine veya bazı tarihsel aktarımlara dayanan şiirlerin, hatta belki de büyük bir destanın mevcut olması gerektiğini, Herodotos'un da Kyros'un gençliği ve ölümüyle ilgili olayları muhtemelen bunlara dayanarak aktardığını belirtmekte, bu nedenle başka antik yazarlardaki bilgilerin Herodotos'ta eksik olduğunu, Kyros'un ölümüyle ilgili başka aktarımların da benzer şekilde süslenerek yeniden tasarlandığını düşünmektedir. Fakat Duncker, şayet Herodotos İran kökenli anlatımlardan yararlandıysa Tomyris'in Kyros'a göre daha 'iyi ve üstün' gösterilmesinin garip olduğunu belirterek, Kyros'un açıç̧a düzenbazlık, aç gözlülük ve kana doymazlıkla suçlanmasını buna örnek göstermektedir. Bu durumun olasılıkla, Kyros'un ölümüyle ilgili olarak tarihçinin Med kökenli bazı şiirlerin etkisinde kalmış olmasından kaynaklandığını ileri süren Duncker'e (1853, 575, 577-578) göre, Medler kendilerini yenilgiye uğratan, devletlerini yıkan birisinin ölümünün böyle utanç verici şekilde olmasıyla yakından ilgileniyor olmalıydılar. Duncker ayrıca Kyros'un gençliği ile ilgili anlatımlarda da yine Med şiirine dair izlerin bulunduğunu belirtmektedir.

Tomyris'in yaşamına dair eldeki kısıtlı bilgilere bu şekilde göz attıktan sonra göz ardı edilmemesi gereken önemli bir hususun daha olduğunu unutmamak gerekir. Bu da, Kyros'un ölümüyle ilgili olarak Tomyris'in adından bile söz etmeyen antik yazarların da mevcut olmasıdır. Weißbach, Pers kralının sonu ile ilgili çeşitli kaynakların bilgi verdiğini, fakat bunlardan bazılarının tarihsel açıdan değer taşımadığını belirterek, Ksenophon'un (Kyr. VIII. 7 vd) onu yatağında rahatça ölen bir filozof gibi göstermesini bu tür anlatımlara örnek verir (krş. Llewellyn-Jones \& Robson 2010, 173). Sancisi-Weerdenburg $(1985,471)$ da, Kyros'un ölümü konusunda kesin bir bilimsel kanıt yerine sadece sözlü geleneğe dayalı bilgiler olduğunu, 
Ksenophon'un da ya bu tür kaynaklardan yararlandığını ya da Pers krallarının ölüm döşeği sahnelerinden etkilenmiş olabileceğini belirtmektedir. Weißbach $(1924,1156)$ geriye kalan anlatımların ise genellikle Kyros'un barbar bir kavimle savaşırken öldüğü teması üzerinde birleştiklerini belirtir. Bunlardan belki de en önemlisi Knidoslu Ktesias olup, ona göre Kyros ölümünden hemen önce Hintlilerin desteklediği Derbiklere karşı bir sefere çıkmıştır. Derbiklerin Massagetlerin bir kolu olduğu da ileri sürülmektedir (Hermann 1930, 2127, 29 vd. Derbikler için ayrica bk. Tomaschek 1905, 237-238; Grakov 2006, 290). Kyros, savaş sırasında atından düşerek bir Hintli tarafından baldırından mızrakla yaralanmış, ardından da adamları tarafından ordugâhına taşınmıştır. Savaş kanlı geçmiş, fakat sonuçsuz kalmış, Amorges olanları haber alınca yirmi bin Saka süvarisiyle Kyros'un yardımına yetişmiştir. Yeniden gerçekleşen savaşta dokuz bin Persli ve otuz bin Derbik ile Derbiklerin kralı Amoraios ve iki oğlu da ölmüștür. Böylece Kyros bölgeyi ele geçirmiş, ancak üç gün sonra Kambyses'i halefi olarak belirledikten sonra aldığ 1 yaradan dolayı ölmüştür. Kambyses de onun cesedini gömülmesi için Pasargadai'a göndermiştir (Duncker 1853, 577 vd.; Hermann 1920, 1799-1800; Sauter 2000, 136; LlewellynJones \& Robson 2010, 173). Daha önce değindiğimiz gibi bazı bilim adamları da Kyros'un ölüsünün düşman eline geçmediğini ve Pasargadai'a gönderildiğini kabul etmektedirler (Osten 1965, 66; Gera 1997, 203; Grakov 2006, 290). Kyros'un sonu hakkındaki bir diğer anlatım da Hellen ve Pers geleneklerini iyi bilen tarihçi Berossos'a ait olup, ona göre de Kyros, Dahalarla yapılan bir savaşta ölmüştür (Grakov 2006, 290, 298). Weißbach (1924, 1157, 4-29) bu anlatımlar 1şığında, Kyros'un Pers krallığının kuzeydoğu veya doğu sınırlarında bir yerde öldüğünü, düşmanlarının da olasılıkla Massagetler (İskitler, Sakalar), Dahalar veya Derbikler olduğunu belirtmektedir (krş. Duchesne-Guillemin 1979a, 418 ve Gera 1997, 203 dn. 61). Grakov (2006, 290) da aynı düşmanlardan söz ederek Kyros'un Uzboy (Amu Derya) sahillerindeki çarpışmalarda öldüğünü vurgulamaktadır. Gera $(1997,203$ dn. 62) da Arakses Nehri’nin yakınlarında Kyros tarafından yaptırılan ve Büyük İskender zamanında hâlen ayakta kaldığı bilinen bir hisarın, onun Massagetlerin yakınlarındaki bu sınır bölgesinde aktif olduğuna işaret ettiğini belirtmektedir (Kyros'un ölüm tarihi MÖ 530 olarak kabul edilmekteyse de bazı araştırmacılar bunu MÖ 529 olarak vermektedir ayrica bk. Weißbach 1924, 1131, 62; Osten 1965, 66; Mallowan 1985 krş. Gera 1997, 203 dn. 60; Wiesehöfer 1999, 1014; Llewellyn-Jones \& Robson 2010, 173 dn. 69; Ambühl 2013, 595).

Sonuç olarak antik yazarlarda Tomyris'in hayatına dair birbiriyle örtüşen veya farklılık gösteren kısıtlı miktarda bilgiye sahip olduğumuz anlaşılmaktadır. Kyros'un ölümüyle bağlantılı olarak Tomyris'ten hiç söz etmeyen birkaç yazar dışında bunların üzerinde uyuştuğu temel hususlar; Tomyris'in İskit (veya Massaget) kraliçesi olması, Pers kralı büyük Kyros'un ona karşı bir sefere çıkması, Tomyris'in onu yenilgiye uğratması ve büyük Pers kralının hayatını bu savaşta kaybetmiş olmasıdır. Herodotos ve kısmen Iustinus dışındaki antik yazarların ortak özelliği ise bu savaşta tuzak kuran kişi olarak yalnızca Tomyris'i göstermeleridir (Ziegler 1937, 1703, 1-3 krş. Gera 1997, 197). Buna karş1l1k, Tomyris hakkında bilgi veren antik yazarların hemen hepsinin arasında önemli farklılıkların olması dikkat çekicidir. Söz gelimi, olaya en yakın kaynağımız durumundaki Herodotos sadece Pers kralı Kyros'un kurduğu tuzaktan bahsederken Tomyris'in uyguladığı herhangi bir taktiğe değinmez ve İskitleri güçlü Pers ordusuna karş1 bir meydan savaşında kazanmış gibi gösterir. Ona göre savaşın sonunda Kyros'un kafası kesilerek Tomyris tarafindan insan kanıla dolu bir çuvala sokulmuştur. Diodoros ise Tomyris'in adını vermediği gibi herhangi bir savaş hilesinden de bahsetmez, ayrıca Kyros'un çarmıha gerildiğini belirtir. Frontinus ise yalnızca Tomyris'in dağ geçitlerine çekilme taktiğinden söz ederek onun Persleri bu şekilde yendiğini anlatır, fakat o da Kyros'un ölümünden söz etmez. Iustinus'un anlattıkları ise kısmen Herodotos'la kısmen de Frontinus'la uyuşur. Polyainos ise He- 
rodotos'ta yer alan şarapl1-yemekli Pers taktiğini ters yüz ederek Tomyris'e uyarlar. Polyainos'a göre Kyros bu olay neticesinde can vermiştir, fakat o da Kyros'un başının kesilmesinden veya çarmıha gerilmesinden söz etmez. Ayrıca yine Iustinus dışındaki bu yazarlarda, gerek savaşın öncesinde gerekse savaş sırasında gerçekleşen olaylara dair Herodotos'un verdiği pek çok detay da yer almamaktadır.

Bu yazarlar arasında en fazla üzerinde durduğumuz kişi ise Polyainos olmuştur. Zira şarapl1yemekli tuzakla ilgili verdiği bilgilerin Herodotos gibi önemli bir kaynakla tam bir tezat teşkil etmesi, her iki yazarın anlattıklarını ayrı ayrı ele alarak doğruluk payının hangisine ait olabileceğini sorgulamamıza yol açmıştır. Değerlendirmelerimize göre Herodotos'un verdiği bilgilerin doğru olduğu, buna karşılık Polyainos'un belki bilerek belki de yararlandığı bazı derleme eserlerden kaynaklanan hatalardan dolayı Tomyris ile ilgili yanlış bir bilgi aktardığı, aslında anlattıklarının yalnızca Herodotos'un ters yüz edilmiş halinden ibaret olduğu anlaşılmaktadır. Buna mukabil, Iustinus ve onu takip eden birkaçı hariç başka yazarlarda da ne Persler ne de İskitler tarafından kurgulanan böyle bir şarapl1-yemekli tuzaktan söz edildiği görülmektedir. İncelememizin ikinci kısmını ise Herodotos haricindeki kaynaklarda anlatılan Tomyris'in 'bozkır savaş taktiği' oluşturmuştur. Bunda da Iustinus ve Frontinus'un birbirleriyle uyuş̧uğu; Herodotos, Diodoros ve Polyainos gibi bazı yazarlarda ise böyle bir taktikten söz edilmediği görülmektedir. Bu noktada Herodotos'un olaya en yakın kaynak olarak böylesine önemli bir olaydan söz etmemiş olması dikkatimizi çekmiştir. Değerlendirmemiz sonucunda, ünlü tarihçinin daha önce belirttiğimiz bazı nedenlerden dolayı bundan bilerek bahsetmediğini, diğer yazarlarda yer alan bu savaş hilesinin İskitlerin bozkır savaş taktiğine tamamen uygun düştüğünü ve bu konuda Herodotos dışındaki yazarların büyük olasılıkla doğru bilgi verdiği sonucuna ulaşmış bulunmaktayız. Bu bağlamda önce de söylediğimiz gibi, hem Perslerin şaraplı-yemekli tuzağından hem de İskitlerin bozkır taktiğinden bahseden Iustinus'u doğruya en yakın bilgiyi aktaran yazar olarak görmek mümkündür.

Tomyris'in bir komutan olarak sergilediği profili değerlendirmek konusunda başka ipuçları da görülebilmektedir. Söz gelimi, Kyros sefere çıkmadan önce Tomyris'in teklifte bulunarak Perslerin üç günlük bir yol boyunca geri çekilmesini ya da istemezlerse kendisinin aynı şekilde geri çekileceğini bildirmesi incelikli bir stratejinin ürünü olsa gerektir. Tomyris büyük olasılıkla İskitlerde âdet olan düşmanı iç bölgelere çekme taktiğinin Kyros tarafindan anlaşılmaması için, isterlerse Perslerin de geri çekilebileceğine dair karşılık esasına dayalı bir teklif sunmuş olmal1dır. Tecrübeli kraliçe, erkek egemen bir toplumda yaşayan Kyros'un bir kadının önünde geri çekiliyor görüntüsü vermemek için İskitlerin topraklarına girmeyi tercih edeceğini ön görerek böyle bir blöf yapmış olmalıdır (ayrıca bk. Gera 1997, 194-195). Bu noktada, Kroisos'un Pers kralına öğüt verirken bir kadının önünde geri çekilmenin ayıp ve katlanılmaz olacağını söylemesi önemlidir (Hdt. I. 207). Tomyris bu planı kurgularken muhtemelen hem onları topraklarına çekmeyi hem de nehirden de yararlanarak geri dönüş yollarını kesmeyi amaçlamaktaydı (Gera 1997, 197). Ancak bu noktada Tomyris ile ilgili eleştirilebilecek önemli bir husus vardır ki, o da terk edilmiş görüntüsü verilen düşman ordugâhına bizzat ilerlemek yerine tecrübesiz oğlu Spargapises'i göndermiş olmasıdır. Nitekim oğlu gerçekten de bunun bir tuzak olduğunu anlamamış ve İskitler büyük kayıp vermiştir. Ayrıca düşmanın eline geçen Spargapises şayet ölmeseydi, bunu Tomyris'e karşı koz olarak kullanabilmesi için Pers kralına büyük bir firsat da sunmuş olacaktı. Tomyris bunu belki oğlunu sınamak ve savaş tecrübesini artırmak ya da ana kuvvetlerini tümüyle tehlikeye atmak yerine daha küçük bir birlik yollayıp mevcut durumu kontrol ettirmek için yapmış da olabilir. Tomyris'in oğlunu göndermeden önce ona verdiği emirleri bilemediğimizden kesin bir yorumda bulunmak güçtür. Belki de Spargapises sadece düşmanı yakından gözetlemek için emir almış, ancak gençliğin verdiği atılganlık ve kendini ispatlamak 
gayretiyle kendiliğinden harekete geçmişti. Şayet bu şekilde olduysa burada uğranılan yenilgide hata payı şüphesiz Tomyris’ten ziyade oğluna aittir. Bu olayın dışında Tomyris'in askerî alandaki yeteneğine dair asıl önemli bilgi ise şüphesiz yukarıda değindiğimiz İskitlere özgü "bozkır savaş taktiğini” başarıla uygulayarak Kyros'un ordusunu dağlara çekip yok etmesidir. İster meydan savaş1 isterse böyle bir taktik sonucunda olsun esas ilgi çekici olan şüphesiz Tomyris'in bir kadın olarak İskitler gibi savaşçı bir ulusa ait büyük askerî kuvvetleri en iyi şekilde sevk ve idare edebilecek dirayete sahip olmasıdır.

Elimizde bulunan kaynakların Tomyris'in ailesi, çocukluk ve gençlik yılları, fiziksel görünümü gibi özel yaşamına dair bilgiler bir yana, savaşçı İskitlere hükmettiği dönem boyunca başka ne gibi faaliyetler gerçekleştirdiği hakkında da suskun kaldıkları görülmektedir (Tomyris'in Orta Çağ'daki çeşitli tasvirleri için bk. Moorman-Uitterhoeve 1995, 685-687). Bu nedenle, Tomyris'in hayat öyküsünün yalnızca Kyros ile mücadelesiyle ilgili olan küçük bir kesiti sunulabilmektedir. Bunun dışında Tomyris'in ele aldığımız olaydan sonra ne kadar yönetimde kaldığı, hangi siyasal, sosyal veya özel konularla meşgul olduğu, hatta ne zaman ve nasıl öldüğü gibi sorular bile yanıtsız kalmaktadır (Kyros'un seferiyle Dareios'unkini karıştıran ve Tomyris'i de Getlerin kraliçesi olarak gösteren Iordanes'in bu konuda verdiği bazı bilgiler için bk. Ziegler 1937, 1704, 37 vd.). Benzer şekilde oğlu Spargapises hakkındaki bilgilerde bile bir tutarsızlık söz konusudur. Kaynaklardan bazıları Spargapises'in ismini verirken, bazıları adını anmadan sadece Tomyris'in oğlu olarak nitelemekte, bazıları ise ondan hiç söz etmemektedirler. Spargapises'in ölümü konusunda da durum böyledir. Gera, şayet elimizdeki tek kaynak Anonymus de Mulieribus olsayd1, Spargapises'in yalnızca düşmana tutsak düşmenin utancıyla kendini öldürdüğünü düşünebileceğimizi, fakat Herodotos’taki anlatımda buna bir de sarhoşluk durumu eklendiğini ve bunun intiharın sebebini daha anlaşılır kıldığını belirtmektedir (Gera 1997, 198199). Gerçekten de esir düştükten kısa süre sonra bu olayın yaşanması elbette ilk başta onun büyük bir utanç ve suçluluk hissettiğini düşündürmektedir. Ancak burada bir parantez açı, Kyros'un onu annesine karşı kullanmasının önüne geçebilmek adına Spargapises'in onurlu bir şekilde kendi yaşamına son vermiş olabileceğini de eklemek isteriz. Onun ölümüyle ilgili asıl tutarsızlık ise bunun sebebinden ziyade 'ne şekilde' olduğuyla ilgilidir. Herodotos, Spargapises'in ayıldıktan sonra Kyros'tan ellerini çözmesini istediğini ve sonra da kendini öldürdüğünü anlatır. Başka kaynaklarda ise onun intihar ettiğinden değil, Pers kralı tarafından öldürüldügünden söz edilir (Val. Max. IX. 10, ext. 1; Iust. I. 8). Gera (1997, 199), aslında Herodotos'taki anlatımın bunlarla bir bakıma benzeştiğini, zira kendisi öldürmese bile ellerini çözmesine izin vermiş olmakla Kyros'un bu genç adamın ölümünden sorumlu olduğunu ileri sürmektedir. Gerçekten de Kyros onun kendi canına kıymaya niyetli olduğunu anlamamış mıydı, yoksa bunu yapmasına göz mü yummuştu? Görüldüğü gibi olayın bir intihar mı olduğunu, yoksa Spargapises'in Kyros tarafindan mı öldürtüldüğünü, dolayısıyla hangi yazarın doğru bilgiyi verdiğini belirlemek zordur. Ancak Kyros'un Spargapises'i koz olarak kullanıp İskit kraliçesini zorda bırakabilme şansına sahip olduğunu düşünürsek bu değerli tutsağı öldürtmesi veya ölmesine 'göz yummuş olması' bizce zayıf bir olasılıktır. Nitekim daha önce sözünü ettiğimiz Kyros ve Saka kraliçesi Sparethra arasındaki savaşta yaşanan olaylar da bu görüşümüzü destekleyici niteliktedir. Bu savaş sırasında kocası Amorges, Perslerin eline tutsak düşmesine rağmen Sparethra kadın ve erkeklerden oluşan büyük bir ordu toplayarak Kyros'u yenilgiye uğratmayı başarır ve Pers ileri gelenlerinden pek çoğu bir yana kralın bazı yakınlarını da esir alır (Weißbach, bu savaşta Kyros'un da esir düştügünü belirtmekteyse de gerek Ktesias'ta gerekse diğer modern kaynaklarda bundan söz edilmemektedir, bk. Weißbach 1924, 1137, 4144 krş. Duncker 1853, 572; Gera 1997, 199; Sauter 2000, 140 dn. 265; Llewellyn-Jones \& Robson 2010, 171). Amorges'in Perslerin eline geçmesi ile Tomyris'in oğlu Spargapises'in Kyros'a esir 
düşmesi arasında aslında bir benzerlik olsa da olaylar farklı yönde gelişmiştir. Nitekim Sparethra esir aldığı Kyros'un yakınları karşııı̆ında kocasını kurtarır, üstelik Amorges kısa süre sonra Kyros'la sik1 bir dostluk da kurar (ayrica bk. Gera 1997, 199-200; Sauter 2000, 136). Tomyris'in oğlu ise Kyros'un tutsağıyken hayatını kaybeder. Bir kadın için tutsaklık sevinçle biterken diğeri için korkunç bir felakete dönüşür. Ancak konumuz açısından asıl ilginç olan, Kyros'un uğradığ 1 hezimete rağmen elinde tutsak olan Amorges'i öfkeye kapılıp öldürtmemiş olmasıdır. Muhtemelen Kyros Saka kraliçesine karşı onu koz olarak elinde tutmayı düşünmüştü. Gerçekten de bu sayede sonradan esir değiş tokuşu yapılabilmiştir. Bu noktada neden benzer bir durum Spargapises için de geçerli olmasın sorusu akla gelmektedir. Keza Spargapises'i elinde tuttuğu sırada Kyros'un intikam almasını gerektirecek bir yenilgi de söz konusu değildi, bilakis ilk savaştan galip çıkmıştı ve onu öldürtmesi için bir sebep de yoktu. Buna karşılık, diğer olaydaki Sparethra'nın elinde önemli Pers esirlerinin olduğu, yenilgiye uğramış olan Tomyris'in ise hiç savaş esirine sahip olmadığı ve bu nedenle esir değiş tokuşunu düşünmesine gerek kalmayan Kyros'un Spargapises'i kolayca öldürtmüş olabileceği de düşünülebilir. Ancak zaten düşman topraklarında bulunan Pers kralının böyle bir kışkırtma sonucunda güçlü İskit ordusunda meydana gelecek infiali ve bunun yaratacağı tehlikeleri hesaba katmadan böyle önemli bir tutsağı yitirmeyi göze alması kanımızca pek mümkün görünmemektedir.

Diğer yandan Gera (1997, 199 dn. 45), Spargapises'in yaşı hakkında Herodotos'un bilgi vermediğini, ancak hem sarhoş olmasının ve hem de intihar etmesinin onun genç ve tecrübesiz bir yaşta oluşuna işaret ettiğini, nitekim daha sonraki bazı yazarlarda da bu yönde ifadeler bulunduğunu belirtmektedir (krş. Iust. I. 8). Bunun ardından da doğru bir gözlemle, en azından Perslerle savaşan bir orduya kumanda edecek yaşta olduğu anlaş1lan Spargapises'in neden Tomyris' in yerine Massagetlerin başında olmadığını sorgulamaktadır. Benzer bir durumun Artemisia için de geçerli olduğunu, onun oğlunun da savaş için uygun yaşta olmasına rağmen Halikarnassos'u kendisinin yönettiğini ve Kserkses'in kuvvetlerine bizzat katıldı̆̆ını belirten Gera (1997, 199), Tomyris' in farklı olarak ancak oğlunun ölümünden ve ordusunun üçte birini kaybettikten sonra savaşa giriştiğini vurgular. Spargapises'in ordunun bir kısmına kumanda edecek yaşta olmasına rağmen annesinin Massaget tahtında oturmasının bizce tek geçerli açıklaması bir orduya kumanda etmekle devlet deneyiminin farklı şeyler olmasıdır ki kocasının tahtta olduğu dönemde Tomyris'in bu yönünü geliştirdiği aşikârdır. Kaldı ki Spargapises, komuta ettiği birlikle tecrübesizliğinin (Iust. I. 8) kurbanı olmuş ve üstlendiği bu görevi bile layığıyla yerine getirememiştir. Bu olay, İskitlerde tahtın varisi olarak uygun yaşta bir erkek evlat olsa bile gerekli tecrübe ve donanıma erişmeden başa geçmesine izin verilmediğini, üstelik annesinin onun yerine bu görevi üstlenebildiğini göstermesi açısından ayrıca önem taşımaktadır. Bilindiği kadarıyla İskit erkekleri arasında birden fazla kadınla evlilik yapma âdeti bulunmaktaydı. Ayrıca kocalarının ölümünün ardından ona eşlik edebilmesi için bu kadınlardan biri öldürülüyordu (Durmuş 1993, 91; Memiş 2005, 72). Diğer yandan, Pazırık'ta eşleriyle beraber ölmeye zorlanmış kadınların kocalarının tabutlarını paylaştı̆̆ 1 ve bunun oradaki erkeklerin tek kadınla evli olduğuna dair bir ipucu olarak değerlendirilebileceği düşünülmektedir (Memiş 2005, 72-73). Büyük olasılıkla Tomyris de kocasının tek eşi olmasına rağmen geleneğin aksine onunla beraber gömülmek zorunda bırakılmamış olması bu bakımdan dikkate değerdir. Bu durum, yukarıda değindiğimiz üzere Spargapises'in henüz iktidar için gereken olgunlukta olmay1şıyla açıklanabileceği gibi, Tomyris'in böyle bir ölüme direnecek kadar söz sahibi olduğuna da işaret etmektedir. Kanımızca, antikçağda oldukça popüler olan bu öyküde kocasının ölümünden sonra Tomyris'in yönetimi eline almasından doğal bir süreç gibi söz edilmesi de, İskitlerde henüz MÖ VI. yüzyılının ikinci yarısında kadınlara verilen değeri ve onların gerektiği zaman siyasal yaşama katılabildiklerini göstermekte, ayrıca Tomyris'in eşiyle beraber gömülmek bir 
yana, böylesine atılgan ve savaşçı bir topluma hükmedecek kadar kudretli bir kadın olduğunu da ortaya koymaktadır (İskit kadınlarının savaşçı yönleri konusunda bk. Durmuş 1993, 90).

Tomyris'in karakter özellikleriyle ilgili başka önemli ipuçları da mevcut olup, bu konuda özellikle Herodotos'un anlatımları ön plana çıkmaktadır. Ünlü tarihçinin eserinde Tomyris, daha olayın ilk başlarından itibaren sağduyulu ve bilge bir kraliçe görünümü çizmektedir. Zira Kyros'un evlenme teklifinin aslında kendi ülkesini ele geçirmek için kurulan bir tuzak olduğunu derhal anlayıp reddetmesi ve ardından savaş hazırlıklarına başlayan Pers kralını seferden vazgeçirmek için makul ve dikkatle seçilmiş sözlerle uyarıp, savaşçı bir kavmin önderi olmasına rağmen sürekli barıştan yana bir görünüm sergilemesi onun bu yönünü yansıtmakta (Gera 1997, 197), aynı zamanda devlet idaresine de aşina olduğuna işaret etmektedir. Gera (1997, 191-193) da Tomyris'in sürekli savaşı engellemek yönünde tavsiyelerde bulunduğunu belirterek, bu nedenle yaşadığ 1 acı tecrübelere rağmen yine de Pers kralına Massagetlerle savaşmayı öneren Kroisos'un aksine, gerçekte Tomyris'in Kyros için 'bilge bir danışman' veya 'trajik bir uyarıcı' görevi üstlendiğini ve daha önce Sandanis'in Kroisos'a verdiği akıllıca öğütleri aslında şimdi onun Kyros'a verdiğini vurgulamaktadır. Muhtemelen Tomyris kral olan eşinden zamanla çok şey öğrenmişti. Ancak Kyros'un İskitlere tuzak kurarak epeyce kayıp verdirmesi ve bir de oğlunu tutsak etmesinin ardından Tomyris'in bu bilge tavrının ansızın değiştiği görülmektedir. Bu andan itibaren $\mathrm{o}$, hem askerlerini yok yere kaybetmiş bir komutan hem de oğlunun tehlikede olduğunu gören öfkeli bir annedir. Nitekim Tomyris kendisine hâkim olamayarak Pers kralına ağır hakaretler eder, bu da yetmez onu kana doyurmakla tehdit eder. Bu öfkenin görünen sebebi Kyros'un hileyle savaşı kazanmış olmasıdır ve özellikle bu hilenin şarapla yapılması üzerine yoğunlaşmaktadır. Zira askerlerinin böyle küçük düşürücü bir tuzağa aldanmış olması onu ayrıca hiddetlendirmiş olmalıdır. Belki de tecrübesiz oğlunu böyle güçlü bir düşmana karşı gönderirken yanında olmamasının pişmanlığı bu kızgınlığın altında yatan diğer bir sebeptir. Ancak Tomyris, tüm benliğini kapladığı anlaşılan bu öfkeye rağmen yine de sağduyulu davranarak, Kyros'a oğlunu kendisine verip ülkesine geri dönmesini öğütlemekten geri kalmamıştır. Şüphesiz bu esnada oğlunun öldüğünü henüz bilmiyordu. Fakat bu acı gerçek ortaya çıktığı zaman, başından beri engellemeye çalıştığı savaş artık onun için de kaçınılmaz olmuştur. Bu andan itibaren Tomyris pek çok kadın gibi gözyaşları içinde feryat etmek yerine intikam peşinde koşan bir karaktere dönüşmüş (Gera 1997, 201 krş. Iust. I. 8) ve âdeta Hellen mitolojisinde katillerin peşini asla bırakmayan Erinys'lerden birisi olmuştur. Bu ölümden sorumlu tuttuğu Kyros suçunun cezasını çekinceye kadar peşini bırakmaya niyeti yoktur. Sonunda Tomyris, Herodotos'un verdiği bilgiye göre ordusuyla doğrudan Perslerin üzerine yürür ki, bu da onun bir savaş stratejisi uygulamayı düşünemeyecek kadar korkunç bir öfkeyle hareket ettiğini göstermektedir. Ünlü tarihçinin betimlediği son sahnede ise, Kyros'un kesik başını kanla dolu bir çuvala sokan Tomyris, okuyucunun gözünde mağrur bir kraliçe olmaktan ziyade, haklı bir öfkeyle ve kan dondurucu bir biçimde oğlunun intikamını alan trajik bir karakterdir. Artık sağduyunun ve asaletin yerini İskitlerin düşmanlarına karşı sergilemeye alışkın oldukları acımasızlık almıştır. Gera, Tomyris'in sadece askerî anlamda değil aynı zamanda acı çeken bir anne olarak da ön plana çıktığına değinerek, onu ağırbaşlılık ve kana susamışlık ile bilgelik ve vahşetin birleştiği gerçek bir Massaget kraliçesi olarak nitelemektedir (Gera 1997, 187, 189). Ancak onun annelik yönüne dair bilgiler arasında bile bazı farklılıkların olması Tomyris hakkındaki belirsizliklerin giderilmesi konusunda yeni ve güvenilir ipuçlarına ihtiyaç duyulduğunu açıkça göstermektedir. Nitekim bazı kaynaklarda Tomyris'in özellikle anneliğine dikkat çekilirken, bazılarında hem bir anne hem de yurdunu savunan cesur bir kraliçe olarak yer almakta; ancak bazı yazarlarda ise ilginç biçimde onun oğlundan bile söz edilmemekte ve yalnızca Kyros'u yenilgiye uğratan savaşçı bir kadın olarak gösterilmektedir (Gera 1997, 198). 


\section{KAYNAKÇA}

\section{Antik Kaynaklar}

Anakr. (= Anakreon) Kullanılan Metin ve Çeviri: Lyra Graeca II. Including Stesichorus, Ibycus, Anacreon and Simonides. Ed.-Trans.: J. M. Edmonds. Cambridge, Massachusetts, London 1964. (The Loeb Classical Library).

Arr. an. (= Arrianos, Anabasis) Kullanılan Metin ve Çeviri: Arrian, Anabasis Alexandri. Trans.: E.I. Robson, Books I-IV. Cambridge, Massachusetts, London 1961. (The Loeb Classical Library).

Diod. (= Diodorus Siculus) Kullanılan Metin ve Çeviri: Diodoros, Griechische Weltgeschichte. Trans.: G. Wirth-O. Veh, Bücher 1-10. Stuttgart 1992.

Frontin. (= Frontinus) Kullanılan Metin ve Çeviri: Frontin, Kriegslisten. Trans.: G. Bendz. Berlin 1963.

Hdt. (= Herodotos) Kullanılan Metin ve Çeviriler: Herodotus. Trans.: A. D. Godley. Cambridge, Massachusetts, London 1966. (The Loeb Classical Library).

Herodotos, Herodot Tarihi. Trans.: M. Ökmen. İstanbul 1991.

Iust. (= Iustinus) Kullanılan Metin ve Çeviri: Iustinus, Philippische Geschichte. Trans.: Chr. Schwarz. Stuttgart 1858.

Ksen. Kyr. (= Ksenophon, Kyroupaideia) Kullanılan Metin ve Çeviri: Xenophon's Cyropaedia II. Trans.: W. Miller. Cambridge, Massachusetts, London 1961. (The Loeb Classical Library).

Lukian. Khar. (= Lukianos, Kharon) Kullanılan Metin ve Çeviri: Lucian. Trans.: A. M. Harmon. Cambridge, Massachusetts, London 1960. (The Loeb Classical Library).

Polyain. (= Polyainos, Strategemata) Kullanılan Metin ve Çeviriler: Polyän's Kriegslisten. Trans.: W.H. Blume - C. Fuchs. Stuttgart 1855.

Polyaenus, Strategems of War 1-2. Trans.: P. Krentz-E.L. Wheeler, Books 1-8. Chicago-Illinois 1994.

Strab. (= Strabon) Kullanılan Metin ve Çeviri: The Geography of Strabo. In Eight Volumes 5, Trans.: H. L. Jones, Vols. VIII. Cambridge, Massachusetts, London 1954. (The Loeb Classical Library).

Thuk. (= Thukydides) Kullanılan Metin ve Çeviri: Thucydides. Trans.: Ch. Forster Smith. Cambridge, Massachusetts, London 1956. (The Loeb Classical Library).

Val. Max. (= Valerius Maximus) Kullanılan Metin ve Çeviri: Memorable Doings and Sayings. Trans.: D. R. Shackleton Bailey, Books VI-IX. Cambridge, Massachusetts, London 2000. (The Loeb Classical Library).

\section{Modern Literatür}

Ambühl A. (2013). "Kyros". DNP Suppl. 8. Historische Gestalten der Antike (2013) 595-602.

Brodersen K. (2010). "Mannhafte Frauen bei Polyainos und beim Anonymus de mulieribus". Ed. K. Brodersen, Polyainos. Neue Studien/Polyaenus. Berlin (2010) 149-159.

Burchard B. (2001). "Sakai". DNP 10 (2001) 1235.

Cluzeau F. (2013). "Platon'un Ruh Kuramında Pathos". Cedrus I (2013) 65-87.

DNP Der Neue Pauly. Enzyklopädie der Antike. Eds. H. Cancik et. al. 1996-.

Duchesne-Guillemin J. (1979a). "Kyros". KP 3 (1979) 417-419.

Duchesne-Guillemin J. (1979b). "Tomyris". KP 5 (1979) 885.

Duncker M. (1853). Geschichte des Altertums 2. Berlin 1853.

Durmuş İ. (1993). İskitler (Sakalar). Ankara 1993.

Durmuş İ. (2008). İskitler (Sakalar). Ankara 2008.

Erim M. (1987). Latin Edebiyatt. İstanbul 1987.

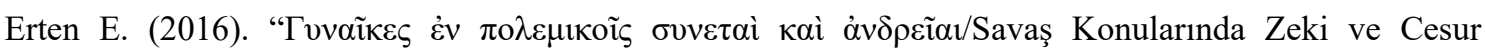
Kadınlar". Libri II (2016) 96-106.

FGrHist Die Fragmente der griechischen Historiker. Ed. F. Jacoby, Dritter Teil, C, Nr. 608a-708, Leiden 1958.

Fuhrmann M. (1979). “Iordanes (1)”. KP (1979) 1439. 
Gera D. (1997). Warrior Women. The Anonymous Tractatus De Mulieribus. New York \& Köln 1997.

Geus K. (2010). "Polyaenus travestitus? Überlegungen zur Biographie des Polyainos und zur Abfassungszeit seines Werks”. Ed. K. Brodersen, Polyainos. Neue Studien/Polyaenus (2010) 55-68. Berlin.

Grakov B. N. (2006). İskitler. Çev. D. A. Batur. İstanbul 2006.

Hasanov Z. (2009). Çar İskitler. İskitler ve Eski Oğuzların Etno-Dil Özdeşleştirmesi. İstanbul 2009.

Hermann A. (1920). "Sakai". RE I/2 (1920) 1770-1806.

Hermann A. (1930). "Massagetai”. RE XIV.2/28 (1930) 2123-2129.

Högemann P. (2002). "Tomyris (Tómupis)”. DNP 12/1 (2002) 673.

Klebs E. (1897). "Boiorix (2)". RE III.1/5 (1897) 636.

KP Der Kleine Pauly. Lexikon der Antike in Fünf Bänden. Ed. K. Ziegler, 1964-1975, Ndr. 1979.

Kroh P. (1972). Lexikon der Antiken Autoren. Stuttgart 1972.

Kytzler B. (1997). Frauen der Antike. Kleines Lexikon Antiker Frauen von Aspasia bis Zenobia. Frankfurt am Main \& Leipzig 1997.

Lammert F. (1952). "Polyainos (8)". RE XXI/42 (1952) 1432-1436.

Llewellyn-Jones L. \& Robson J. (2010). Ctesias' History of Persia. Tales of the Orient. London \& New York 2010.

Mallowan M. (1985). "Cyrus the Great (558-529 B.C.)". CHI 2/1 (198) 392-419.

Meister K. (2001). "Polyainos (Пoגúaıvos)(4)”. DNP 10 (2001) 40-41.

Melber J. (1885). Über die Quellen und den Wert der Strategemensammlung Polyäns. Leipzig 1885.

Memiş E. (2005). İskitlerin Tarihi. Konya 2005.

Moorman E. M. \& Uitterhoeve W. (1995). Lexikon der Antiken Gestalten. Mit ihrem Fortleben in Kunst, Dichtung und Musik. Stuttgart 1995.

Obst E. (1927). "Spargapises". RE III/5 (1927) 1262.

Osten von der H. H. (1965). Die Welt der Perser. Stuttgart 1965.

RE Pauly's Real-Encyclopädie der classischen Altertums-wissenschaft. Eds. G. Wissowa et al. Neue Bearbeitung, 1893-1980.

Rolle R. (1980). Die Welt der Skythen. Stutenmelker und Pferdebogner: Ein antikes Reitervolk in neuer Sicht. Luzern \& Frankfurt/M 1980.

Sancisi-Weerdenburg H. (1985). "The Death of Cyrus". Acta Iranica 2 (1985) 459-471.

Sauter H. (2000). Studien zum Kimmerier Problem. Bonn 2000.

Schiltz V. (1994). Die Skythen und Andere Steppenvölker. 8. Jahrhundert v. Chr. bis 1. Jahrhundert n. Chr. München 1994.

Tezcan M. (2014). “Turkmenia'da Hüküm Süren Önemli Bir Kabile Olarak Sakaların (A)Parni Boyu ve Bunun, İran'ın Kuzey-Doğu Bölgesi Horasan'daki Apar Bölgesi ile Alâkası". Cedrus II (2014) 55-74.

Tomaschek W. (1905). "Derbikes". RE V/10 (1905) 237-238.

Ünsal F. (1997). Platon'da Aşk Kavramı. Yayımlanmamış Yüksek Lisans Tezi. Ankara Üniversitesi, Sosyal Bilimler Enstitüsü, Ankara 1997.

Weißbach F. H. (1924). “Kyros (6)”. RE Suppl. 4 (1924) 1129-1166.

Wiesehöfer J. (1999). "Kyros (II. ?) (2)”. DNP 6 (1999) 1014-1017.

Ziegler K. (1937). “Tomyris”. RE VI/12 (1937) 1702-1704. 